
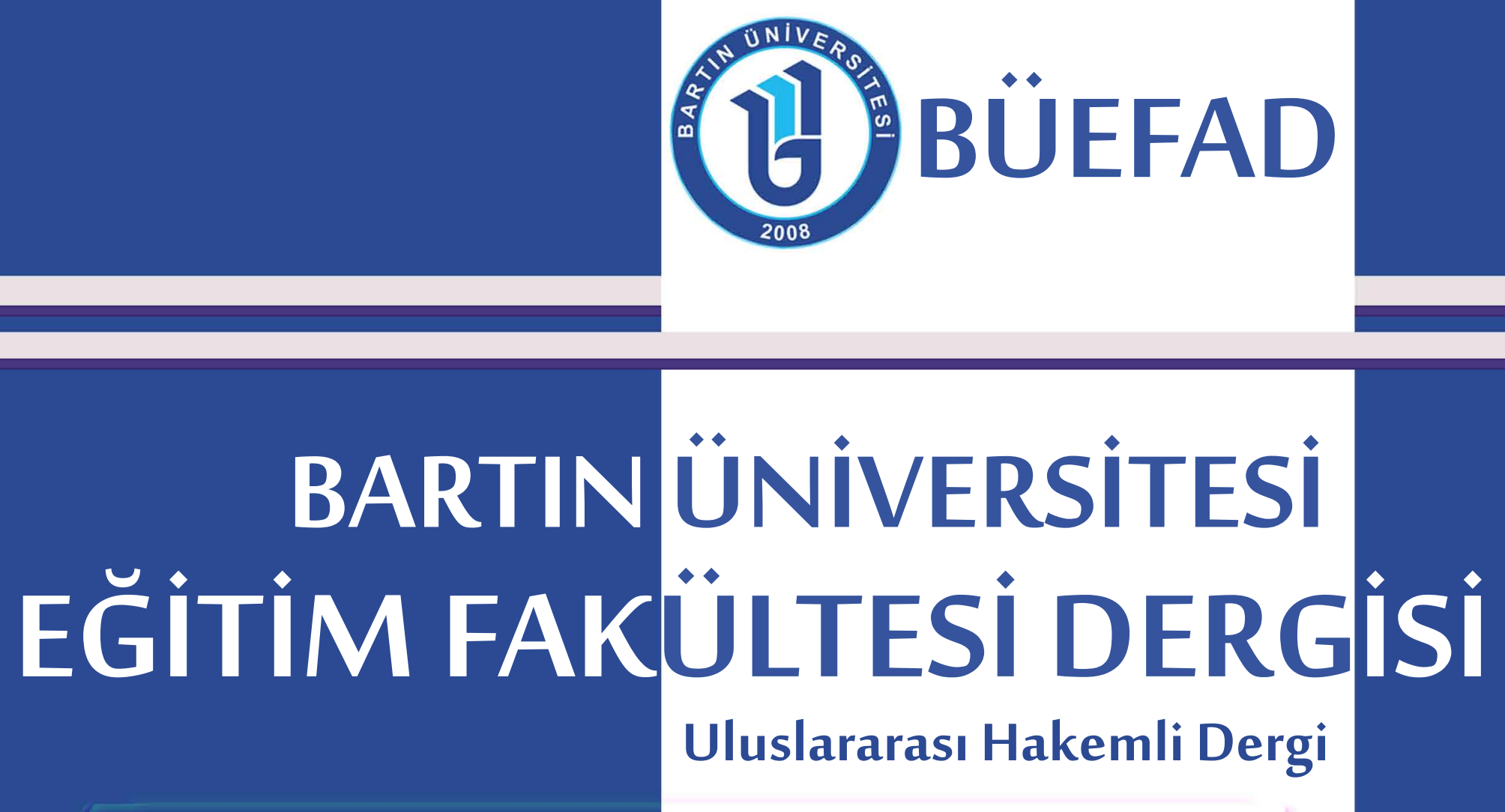

- AYRI BASIM - $\quad$ - SPECIAL EDITION -

Yrd. Doç. Dr. Özcan Erkan AKGÜN - Şirin KÜçÜK $\quad$ Asst. Prof. Ozcan Erkan AKGUN - Sirin KUCUK Barış ÇUKURBAŞI - İsmail TONBULOĞLU Baris CUKURBASI - Ismail TONBULOGLU

Sözel veya Görsel Baskın Öğrenme Stilini Belirleme Ölçeği Türkçe Formunun Geçerlik ve Güvenirlik Çalışması

Validity and Reliability Study of the Visual versus Verbal Style of Processing Scale Turkish Form

BARTINUNIVERSITY JOURNAL

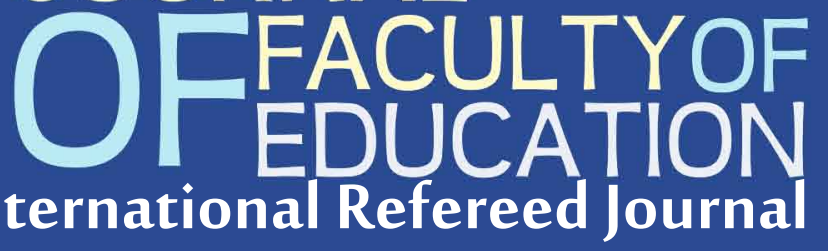

Cilt/Volume: $3 \quad$ Sayı/Issue: 1

Yaz/Summer 2014 ISSN 1308-7177
ProcessForm

Objectives

Pre-Service

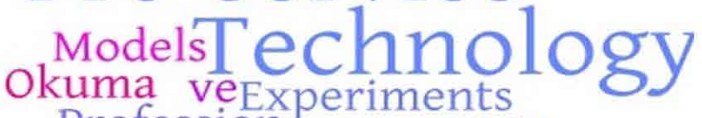

Profession

Verbal Supervision

Study Investigating Turkish

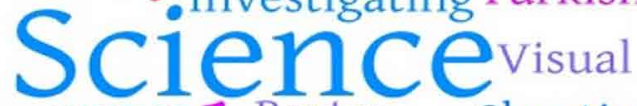

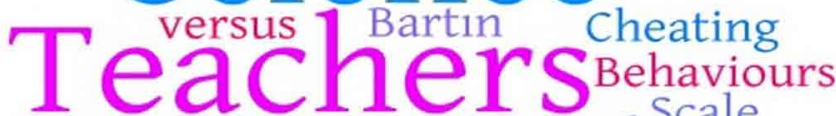

Candidatestowards

Education Approaches ölçeğinin

Digital Supervisors

Teacher Mathematics Profiles

Examination Processing

Assisted Reliability Alg1sı

ÖzyeterlilikEleştirel

Attitudes ${ }^{\text {Style }}$

Teaching Features University

Güvenirlik Geçerlilik

Çalışması Analysis

Example Speech 


\section{BARTIN ÜNIVERSİTesi EĞítim FAKüLTESI DERgisi}

BARTIN UNIVERSITY JOURNAL OF FACULTY OF EDUCATION

Cilt/ Volume: 3, Say1/Issue: 1, Yaz / Summer 2014

ISSN:1308-7177

\section{$\underline{\text { Sahibi }}$}

Bartın Üniversitesi Eğitim Fakültesi Adına Prof. Dr. Firdevs GÜNEŞ (Dekan)

Editör

Yrd. Doç. Dr. Sedat BALYEMEZ

\section{Alan Editörleri}

Doç. Dr. Çetin SEMERCi

Doç. Dr. Necati HIRÇA

Doç. Dr. Nuriye SEMERCi

Yrd. Doç. Dr. Ayşe Derya IŞIK

Yrd. Doç. Dr. Meliha KÖSE

Yrd. Doç. Dr. Neslihan USTA

Yrd. Doç. Dr. Sevan NART

Yrd. Doç. Dr. Sinem TARHAN

Yrd. Doç. Dr. Süreyya GENÇ

Yabancı Dil Sorumlusu

Yrd. Doç. Dr. Özge GÜN

\section{Yayıma Hazırlık}

Arş. Gör. Arzu ÇEVIK

Arş. Gör. Ömer KEMiksiz

\section{Sekretarya}

Arş. Gör. Hasan Basri KANSIZOĞLU

\section{Teknik Sorumlular}

Arş. Gör. Barış ÇUKURBAŞı

Arş. Gör. Fatma Gizem KARAOĞLAN YILMAZ

\section{İetişim}

Bartın Üniversitesi Eğitim Fakültesi

74100 BARTIN - TÜRKIYE

e-posta: buefad@bartin.edu.tr

Tel: +903782235219

Bartın Üniversitesi Eğitim Fakültesi Dergisi (BÜEFAD), yılda iki kez yayımlanan uluslararası hakemli bir dergidir. Yazıların sorumluluğu, yazarlarına aittir.
Owner

On Behalf of Bartin University Faculty of Education Prof. Firdevs GUNES (Dean)

$\underline{\text { Editor }}$

Asst. Prof. Sedat BALYEMEZ

Field Editors

Assoc. Prof. Cetin SEMERCI

Assoc. Prof. Necati HIRCA

Assoc. Prof. Nuriye SEMERCI

Asst. Prof. Ayse Derya ISIK

Asst. Prof. Meliha KOSE

Asst. Prof. Neslihan USTA

Asst. Prof. Sevan NART

Asst. Prof. Sinem TARHAN

Asst. Prof. Sureyya GENC

Foreign Language Specialist

Asst. Prof. Ozge GUN

Preparing for Publication

RA. Arzu CEVIK

RA. Omer KEMIKSIZ

Secretary

RA. Hasan Basri KANSIZOGLU

$\underline{\text { Technical Assistants }}$

RA. Baris CUKURBASI

RA. Fatma Gizem KARAOGLAN YILMAZ

Contact

Bartin University Faculty of Education 74100 BARTIN - TURKEY

e-mail: buefad@bartin.edu.tr

Tel: +90 3782235219

Bartin University Journal of Faculty of Education (BUJFED) is a international refereed journal that is published two times a year. The responsibility lies with the authors of papers. 


\section{DiZINLENME VE LISTELENME / INDEXING AND LISTING}

Bartın Üniversitesi Eğitim Fakültesi Dergisi, aşağıdaki indeksler tarafından dizinlenmekte ve listelenmektedir. / Bartin University Journal of Faculty of Education is indexed and listed by the following indexes.

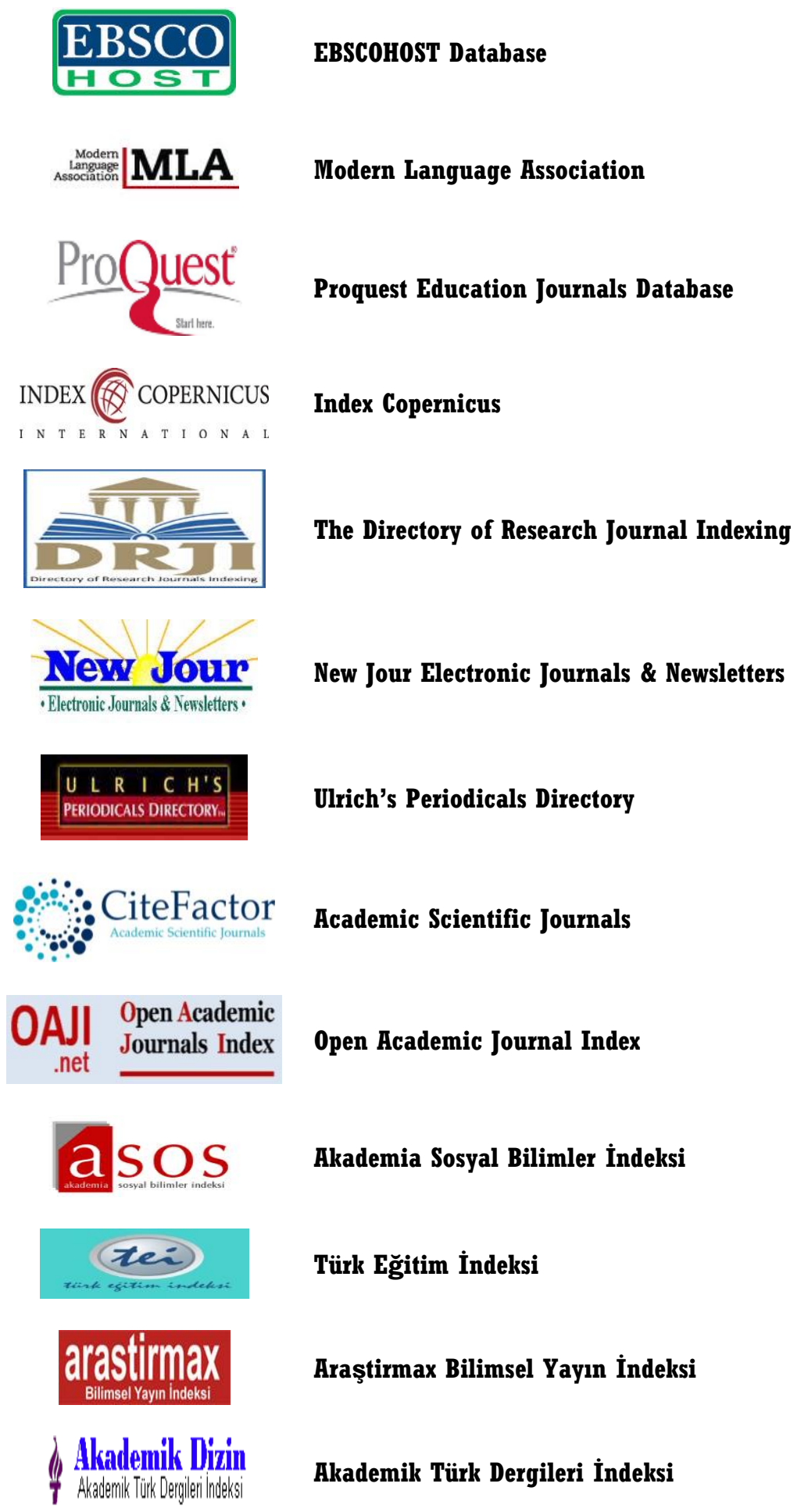


YAYIN DANIŞMA KURULU / EDITORIAL ADVISORYBOARD

Prof. Dr. Ahmet ARIKAN

Prof. Dr. Ahmet GÜNŞEN

Prof. Dr. Ahmet SABAN

Prof. Dr. Aziz KILINÇ

Prof. Dr. Bilgin Ünal iBRET

Prof. Dr. Cemal TOSUN

Prof. Dr. Firdevs GÜNEŞ

Prof. Dr. Firdevs KARAHAN

Prof. Dr. Ahmet KIRKILIÇ

Prof. Dr. Hayati AKYOL

Prof. Dr. Hüseyin ALKAN

Prof. Dr. M. Fatih TAŞAR

Prof. Dr. Mimar TÜRKKAHRAMAN

Prof. Dr. Murat ÖZBAY

Prof. Dr. Ramazan KAPLAN

Prof. Dr. Recai DOĞAN

Prof. Dr. Safure BULUT

Prof. Dr. Sebahattin ARIBAŞ

Prof. Dr. Selahattin TURAN

Prof. Dr. Selma YEL

Prof. Dr. Şefik YAŞAR

Prof. Dr. Yavuz TAŞKESENLIGIL

Doç. Dr. Bahri ATA

Doç. Dr. Çavuş ŞAHIN

Doç. Dr. Çetin SEMERCi

Doç. Dr. Emine KOLAÇ

Doç. Dr. Erol DURAN

Doç. Dr. Eyyüp COŞKUN

Doç. Dr. Kubilay YAZICI

Doç. Dr. Neşe TERTEMiz

Doç. Dr. Nuriye SEMERCi

Doç. Dr. Sabri SIDEKLi

Doç. Dr. Tolga GÜYER
Gazi Üniversitesi

Trakya Üniversitesi

N. Erbakan Üniversitesi

ÇOMÜ

Kastamonu Üniversitesi

Ankara Üniversitesi

Bartın Üniversitesi

Sakarya Üniversitesi

Atatürk Üniversitesi

Gazi Üniversitesi

Dokuz Eylül Üniversitesi

Gazi Üniversitesi

Akdeniz Üniversitesi

Gazi Üniversitesi

Bartın Üniversitesi

Ankara Üniversitesi

ODTÜ

Adıyaman Üniversitesi

Osmangazi Üniversitesi

Gazi Üniversitesi

Anadolu Üniversitesi

Atatürk Üniversitesi

Gazi Üniversitesi

ÇOMÜ

Bartın Üniversitesi

Anadolu Üniversitesi

Uşak Üniversitesi

Mustafa Kemal Üniversitesi

Niğde Üniversitesi

Gazi Üniversitesi

Bartın Üniversitesi

Muğla S. Koçman Üniversitesi

Gazi Üniversitesi 


\section{BU SAYININ HAKEMLERI / REFEREES OFTHIS ISSUE}

Prof. Dr. Ahmet KAÇAR

Prof. Dr. Adnan BAKi

Prof. Dr. Fatma AÇIK

Prof. Dr. Firdevs GÜNEŞ

Prof. Dr. Firdevs KARAHAN

Prof. Dr. Hasan BACANLI

Prof. Dr. Yusuf BUDAK

Doç. Dr. Ali TAŞ

Doç. Dr. Çetin SEMERCi

Doç. Dr. Ebru KILIÇ ÇAKMAK

Doç. Dr. Eyyüp COŞKUN

Doç. Dr. Halit KARATAY

Doç. Dr. Gökhan DEMIRCioĞLU

Doç. Dr. Levent ERASLAN

Doç. Dr. Mehmet Ali ÇAKMAK

Doç. Dr. Mehmet Altan KURNAZ

Doç. Dr. Mustafa ULUSOY

Doç. Dr. Mübin KIYICI

Doç. Dr. Necati HIRÇA

Doç. Dr. Nuriye SEMERCi

Doç. Dr. Orhan AKINOĞLU

Doç. Dr. Özay KARADAĞ

Doç. Dr. Özlem ÇAKMAK

Doç. Dr. Sabri SIDEKLI

Doç. Dr. Yüksel GÖĞEBAKAN

Yrd. Doç. Dr. Abdullah Çağrı BiBBER

Yrd. Doç. Dr. Ahmet YIKMIŞ

Yrd. Doç. Dr. Ahmet AKKAYA

Yrd. Doç. Dr. Ali Rıza ŞEKERCi

Yrd. Doç. Dr. Aslıhan SABAN

Yrd. Doç. Dr. Aynur KOLBURAN GEÇER

Yrd. Doç. Dr. Ayşe Derya IŞIK

Yrd. Doç. Dr. Ayşe GÜLER

Yrd. Doç. Dr. Burcu DUMAN

Yrd. Doç. Dr. Cemal TOSUN

Yrd. Doç. Dr. Çığıl AYKUT

Yrd. Doç. Dr. Devrim AKGÜNDÜZ

Yrd. Doç. Dr. Fulya TOPÇUOĞLU ÜNAL

Yrd. Doç. Dr. Gamze Elif TANINMIŞ

Yrd. Doç. Dr. Güliz AYDIN

Yrd. Doç. Dr. İbrahim GÖKTAŞ

Yrd. Doç. Dr. İlhan YALÇIN
Kastamonu Üniversitesi

Karadeniz Teknik Üniversitesi

Gazi Üniversitesi

Bartın Üniversitesi

Sakarya Üniversitesi

Yıldız Teknik Üniversitesi

Gazi Üniversitesi

Kırıkkale Üniversitesi

Bartın Üniversitesi

Gazi Üniversitesi

Mustafa Kemal Üniversitesi

Abant İzzet Baysal Üniversitesi

Ondokuz Mayıs Üniversitesi

Kırıkkale Üniversitesi

Gazi Üniversitesi

Kastamonu Üniversitesi

Gazi Üniversitesi

Sakarya Üniversitesi

Bartın Üniversitesi

Bartın Üniversitesi

Marmara Üniversitesi

Düzce Üniversitesi

Gazi Üniversitesi

Muğla Sıtkı Koçman Üniversitesi

İnönü Üniversitesi

Kastamonu Üniversitesi

Abant İzzet Baysal Üniversitesi

Adıyaman Üniversitesi

Dumlupınar Üniversitesi

Konya Üniversitesi

Kocaeli Üniversitesi

Bartın Üniversitesi

Kırıkkale Üniversitesi

Bartın Üniversitesi

Bartın Üniversitesi

Gazi Üniversitesi

İstanbul Aydın Üniversitesi

Dumlupınar Üniversitesi

Gazi Üniversitesi

Ordu Üniversitesi

Adnan Menderes Üniversitesi

Ankara Üniversitesi 
Yrd. Doç. Dr. M. Sani ADIGÜZEL

Yrd. Doç. Dr. Mehmet Diyaddin YAŞAR

Yrd. Doç. Dr. Mehmet UMUZDAŞ

Yrd. Doç. Dr. Metin DENIZ

Yrd. Doç. Dr. Murat GENÇ

Yrd. Doç. Dr. Nail iLHAN

Yrd. Doç. Dr. Nalan OKAN AKIN

Yrd. Doç. Dr. Nuray MAMUR

Yrd. Doç. Dr. Özcan KARAASLAN

Yrd. Doç. Dr. Özge GÜN

Yrd. Doç. Dr. Sedat BALYEMEZ

Yrd. Doç. Dr. Semra KIRANLI GÜNGÖR

Yrd. Doç. Dr. Sibel SADI

Yrd. Doç. Dr. Suad SAKALLI GÜMÜŞ

Yrd. Doç. Dr. Sultan Bilge KARA

Yrd. Doç. Dr. Süleyman AVCI

Yrd. Doç. Dr. Şenel ELALDI

Yrd. Doç. Dr. Şeyda GÜL

Yrd. Doç. Dr. Tolga KABACA

Yrd. Doç. Dr. Tuncay Yavuz ÖZDEMiR

Yrd. Doç. Dr. Yakup DOĞAN

Dr. Hayriye Tuğba ÖZTÜRK
İstanbul Aydın Üniversitesi

Kilis 7 Aralık Üniversitesi

Gaziosmanpaşa Üniversitesi

Bartın Üniversitesi

Düzce Üniversitesi

Kilis 7 Aralık Üniversitesi

Niğde Üniversitesi

Pamukkale Üniversitesi

Marmara Üniversitesi

Bartın Üniversitesi

Bartın Üniversitesi

Eskişehir Osmangazi Üniversitesi

Kafkas Üniversitesi

Mustafa Kemal Üniversitesi

Okan Üniversitesi

Marmara Üniversitesi

Cumhuriyet Üniversitesi

Atatürk Üniversitesi

Pamukkale Üniversitesi

FIrat Üniversitesi

Kilis 7 Aralık Üniversitesi

Ankara Üniversitesi 


\section{IÇINDEKILER / CONTENTS}

\section{Prof. Dr. Firdevs GÜNEŞ}

Konuşma Öğretimi Yaklaşım ve Modelleri

Speech Teaching Approaches and Models

doi number: 10.14686/BUEFAD.201416205

\section{Barış ÇUKURBAŞı - Prof. Dr. Aytekin IŞMAN}

Öğretmen Adaylarının Dijital Yerli Özelliklerinin Incelenmesi (Bartın Üniversitesi Örneği)

Examination of Teacher Candidates' Digital Natives Features (Example of Bartın University)

doi number: 10.14686/BUEFAD.201416206

Yrd. Doç. Dr. Süleyman GÖKSOY - Doç. Dr. Engin ASLANARGUN

Denetim Sürecinde Eğitim Denetmenlerinin Davranışları

Behaviours of Supervisors in the Process of Supervision

$55-77$

doi number: 10.14686/BUEFAD.201416207

Arş. Gör. Yunus ÖZYURT - Doç. Dr. Altay EREN

Fen Bilgisi Öğretmen Adaylarının Öğretmenlik Mesleğine ve Kopya Çekmeye Yönelik Tutumlarının Görünümü

Profiles of Pre-Service Science Teachers' Attitudes towards the Teaching Profession and Cheating doi number: 10.14686/BUEFAD.201416208

\section{Yrd. Doç. Dr. Sefa DÜNDAR}

The Investigation of Spatial Skills of Prospective Teachers with Different Cognitive

Bilissel Stilleri Farklı Ogretmen Adaylarının Uzamsal Becerilerinin Incelenmesi

doi number: 10.14686/BUEFAD.201416209

Yrd. Doç. Dr. Abdulkerim KARADENiz

Eleştirel Okuma Özyeterlilik Algısı Ölçeğinin Geçerlilik ve Güvenirlik Çalışması

Critical Reading Self-Efficacy Perception Scale Validity and Reliability Study

doi number: 10.14686/BUEFAD.201416210

Yrd. Doç. Dr. Ayşen KARAMETE - Öğr. Gör. Hüseyin GÜNEŞ

İlköğretim Seçmeli Satranç Dersi Başlangıç Düzeyi Birinci Basamak Bilgisayar Destekli Öğretim Tasarımı

Primary School First Grade Beginner Level Chess Course Computer-Aided Instructional Design

doi number: 10.14686/BUEFAD.201416211

Doç. Dr. Fahri TEMizYÜREK - Arş. Gör. Arzu ÇEVIK

Mustafa Ruhi Şirin'in Çocuk Edebiyatı Sahasındaki Eserlerinin Dil ve Kavram Bağlamında İncelenmesi

Examination of Mustafa Ruhi Sirin's Works in Field of Children's Literature According to Context of Language

Concept

doi number: 10.14686/BUEFAD.201416212

Dr. Gizem KARAOĞLAN YILMAZ - Dr. Ramazan YILMAZ - Arş. Gör. Barış SEZER

Üniversite Öğrencilerinin Güvenli Bilgi ve İletişim Teknolojisi Kullanım Davranışları ve Bilgi Güvenliği Eğitimine Genel Bir Bakış

Secure Information and Communication Technology Usage Behavior of University Students and an Overview

to Information Security Training

$176-199$

doi number: 10.14686/BUEFAD.201416213 


\section{IÇINDEKILER / CONTENTS}

\section{Yrd. Doç. Dr. Erdal TAŞLIDERE}

Kavramsal Değişim Yaklaşımının Doğru Akım Devreleri Konusundaki Kavram Yanılgılarının Giderilmesine Etkisi

Effect of Conceptual Change Instruction on Remedying Misconceptions Concerning Direct Current Circuits doi number: 10.14686/BUEFAD.201416214

\section{Dr. H. Tuğba ÖzTÜRK}

Küreselleşme ve Ağ Toplumları Odağında Bilgi ve Illetişim Teknolojileri ile Eğitim Education with Information and Communication Technologies in the Scope of Globalisation and Network Society doi number: 10.14686/BUEFAD.201416215

Yrd. Doç. Dr. Serkan TiMUR - Şirin YILMAZ - Yrd. Doç. Dr. Betül TiMUR Fen ve Teknoloji Öğretmenleri İle Öğretmen Adaylarının Fen Deneylerinin Amaçlarını Kavramaya Yönelik Tutumlarının İncelenmesi Investigating Science and Technology Teachers' and Pre-Service Teachers' Attitudes towards Understanding the Objectives of Science Experiments doi number: 10.14686/BUEFAD.201416216

\section{Fazilet Eda YILMAZ - Gülşah TOPALOĞLU - Mustafa AKYÜZLÜER}

Grupla Yapılan Müzik Etkinliğinin Otizmli Çocukların Sosyal Becerilerine Etkisinin Betimlenmesi

Description of the Effect of Musical Activity with Group on Social Skills of Children with Autism doi number: 10.14686/BUEFAD.201416217

Yrd. Doç. Dr. Özcan Erkan AKGÜN - Şirin KÜçÜK

Barış ÇUKURBAŞI - İsmail TONBULOĞLU

Sözel veya Görsel Baskın Öğrenme Stilini Belirleme Ölçeği Türkçe Formunun Geçerlik ve Güvenirlik Çalışması

Validity and Reliability Study of the Visual versus Verbal Style of Processing Scale Turkish Form doi number: 10.14686/BUEFAD.201416218

Arş. Gör. Ruhşen ALDEMiR - Doç. Dr. Enver TATAR Teknoloji Destekli Matematik Eğitimi Hakkında Yayınlanan Makalelerinin İncelenmesi An Analysis of Articles on Technology Assisted Mathematics Education doi number: 10.14686/BUEFAD.201416219

İsmail TONBULOĞLU - Prof. Dr. Aytekin IŞMAN

Öğretmenlerin Sosyal Ağları Kullanım Profillerinin İncelenmesi

Exploring Teachers' Social Network Usage

doi number: 10.14686/BUEFAD.201416220

Arş. Gör. Dr. Osman çiMEN - Prof. Dr. Mehmet YILMAZ Dönüşümsel Öğrenme Kuramına Dayalı Çevre Eğitiminin Biyoloji Öğretmen Adaylarının Çevre Sorunlarına Yönelik Algılarına Etkisi The Influence of Transformative Learning Based Environmental Education on Preservice Biology Teachers' Perception of Environmental Problems doi number: 10.14686/BUEFAD.201416221

Doç. Dr. İ. Halil TÜRKER - Yrd. Doç. Dr. Fatih ÖZDEMiR Resim-İş Eğitimi Programları Grafik Ana Sanat Ders İçerikleri ve İşleniş Biçimleri Course Outlines and Teaching Styles at Graphic Design Lessons at Fine Arts Education Departments doi number: 10.14686/BUEFAD.201416222 


\section{IÇINDEKILER / CONTENTS}

\section{Yrd. Doç. Dr. Süreyya GENÇ}

Sanat Eğitiminde Eğitsel Oyunların Önemi

Importance of Educational Games in Arts Education

doi number: 10.14686/BUEFAD.201416223

Doç. Dr. Lale HÜSEYNOVA

Müzik Öğretmenliği Bölümü Öğrencilerinin Keman Çalma Performanslarını Etkileyen Bazı Değişkenler

Some Variables that Affect the Violin - Playing Performance of Students in the Department of Music Teaching doi number: 10.14686/BUEFAD.201416224

\section{Yrd. Doç. Dr. Vafa SAVAŞKAN}

Eğitim Fakültesi Öğrencilerinin Günlük Tutma Alışkanlıklarının Öğrenci Görüşleri Doğrultusunda İncelenmesi

Investigate the Logging Habits of the Faculty of Education Students in Terms of Students' Opinion doi number: 10.14686/BUEFAD.201416225

Arş. Gör. Melehat GEZER - Prof. Dr. İbrahim Fevzi ŞAHIN

Yrd. Doç. Dr. Meral ÖNER SÜNKÜR - Arş. Gör. Elif MERAL

8. Sınıf Türkiye Cumhuriyeti İnkılâp Tarihi ve Atatürkçülük Dersi Öğretim Programı Kazanımlarının Revize Edilmiş Bloom Taksonomisine Göre Değerlendirilmesi

An Evaluation of the Outcomes of the 8th Grade History of Turkish Revolution and Kemalism Lesson According to Revized Bloom's Taxonomy doi number: 10.14686/BUEFAD.201416226

Prof. Dr. Firdevs GÜNEŞ - Doç. Dr. Coşkun ARSLAN - Arş. Gör. Ayşe ELiÜşÜK Atılganlık Eğitiminin Üniversite Öğrencilerinin Kişiler Arası Problem Çözme, Algılanan Sosyal Destek ve Atılganlık Düzeyleri Üzerine Etkisi 

Bartın Üniversitesi
Eğitim Fakültesi Dergisi
Cilt 3, Sayı 1, s. 277 - 297, Yaz 2014
BARTIN - TÜRIKIYE

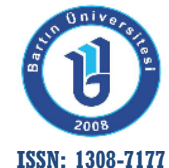

\title{
Sözel veya Görsel Baskın Öğrenme Stilini Belirleme Ölçeği Türkçe Formunun Geçerlik ve Güvenirlik Çalışması
}

\author{
Yrd. Doç. Dr. Özcan Erkan AKGÜN \\ Sakarya Üniversitesi \\ ozcanakgun@gmail.com
}

\author{
Barış ÇUKURBAŞI \\ Sakarya Üniversitesi \\ bariscukurbasi@gmail.com
}

\author{
Şirin KüçüK \\ Sakarya Üniversitesi \\ sirinkucuk@gmail.com \\ İsmail TONBULOĞLU \\ Sakarya Üniversitesi \\ ismailtonbul@gmail.com
}

\begin{abstract}
Özet: Öğretim içeriğinin, öğretim yöntem ve tekniklerinin seçilmesinde ve uygulanmasında bireysel özelliklerin göz önünde tutulması gerekliliği öne çıkmaktadır. Bu bağlamda bireyin bilgiyi işleme stilini bilmek, bireyin öğrenme ortamlarından daha etkili bir şekilde yararlanmasına yardımcı olacaktır. Bilgiyi işleme stillerinden biri de sözel ve görsel öğrenme stilidir. Öğrencilerin sözel veya görsel baskın tercihini belirlemek için ölçme araçlarına ihtiyaç duyulmaktadır. Bu çalışmanın amacı Childers, Houston ve Heckler (1985) tarafından sözel ya da görsel baskın öğrenme stilini belirlemek için geliştirilen Bilgiyi İşleme Stili Ölçeğini (Style of Processing Scale) Türkçeye uyarlamaktır. Ölçeğin Türkçeye uyarlama çalışmaları çerçevesinde, ölçek ilk olarak araştırmacılar tarafından Türkçeye çevrilmiştir. Özgün İngilizce maddeleri ve çevrilen Türkçe maddeleri içeren bir uzman görüşü formu hazırlanarak 9 uzmandan görüş alınarak gerekli düzenlemeler yapılmıştır. Ayrıca Türkçe maddelerin öğrenciler tarafından anlaşııılığı incelenmiştir. Bu işlemin ardından özgün ölçekteki maddeler ile Türkçe ölçek maddeleri arasındaki eşdeğerliğin kontrolü bu iki dili çok iyi bilen öğrencilerden alınan yanıtların incelenmesi ile yapılmışır. Aynı kişilerden elde edilen farklı dildeki iki formun puanları arasında Pearson momentler çarpımı korelasyon katsayısı hesaplanarak, değerin 0.94 olduğu bulunmuştur. Bu işlemin ardından ölçek 240 öğretmen adayına uygulanmışır. Ölçekten elde edilen verilere yapı geçerliliği için doğrulayııı faktör analizi uygulanmış, ölçeğin Cronbach alpha iç tutarlık katsayıları, düzeltilmiş madde toplam korelasyon değerleri ve alt \%27 ve üst \%27 grupların madde toplam korelasyon puanları hesaplanmıştır. Araştırma sonucunda Türkçeye uyarlaması yapılan öğrenme stilleri ölçeğinin geçerli ve güvenilir olduğu ortaya çıkmışıı. Geliştirilen ölçeğin ilgili olabilecek başka değişkenlerle ilişkilerinin incelenmesi açısından bilimsel araştırmalarda, uyarlamalı-destekleyici öğrenme materyallerinin geliştirilmesi ve kullanılmasında, öğrenmeöğretme süreçlerinde kullanılması umulmaktadır.
\end{abstract}

Anahtar Kelimeler: Görsel Öğrenme, Sözel Öğrenme, Öğrenme Stilleri

\section{Validity and Reliability Study of the Visual versus Verbal Style of Processing Scale Turkish Form}

\begin{abstract}
Individual differences are very important to consider before choosing instructional methods and techniques properly. One of these differences is style of processing with visual versus verbal. Knowing individuals' style of processing can give us an opportunity to design more individualized teaching and learning processes, and also learning systems. But first we need an instrument to identify dominant style of processing. The aim of this study is to adapt Style of Processing (SOP) Scale developed by Childers, Houston and Heckler (1985) in to Turkish audiences. In order to accomplish this aim, we first translated original English items into Turkish by taking views of 9 experts. Additionally we took students views on translated Turkish items to confirm their meaning and clarity. After that we applied both English and Turkish forms of the scale on a group of people knowing English and Turkish very well that they could be assumed as bilinguals. Pearson correlation coefficient of two application calculated as 0.94 , that shows a significant, positive and strong correlation. After completing the equivalency study we applied the scales on 240 teachers students. We used confirmatory factor analysis, Cronbach alpha internal consistency coefficient, corrected item-total correlations, and t test to compare top $\% 27$ and down $\% 27$ groups' meanings differences. All of these analyses gave satisfactory results. According to these results it can be said that Turkish form of SOP Scale is a valid and a reliable instrument.
\end{abstract}

We hope that the scale will be used in future scientific research, developing and implementing adaptive-assistive learning systems, and teaching-learning processes.

Key Words: Visual Learning, Verbal Learning, Style of processing, SOP, Learning Styles. 


\section{GiRiş}

Öğretimin gerçekleştirilmesinde, öğretim içeriğinin, öğretim yöntem ve tekniklerinin seçilmesinde bireysel özelliklerin göz önünde tutulması gerekliliği birçok çalışmada yer almaktadır. Öğrenme stilleri bireyin doğuştan sahip olduğu ve bireyin başarısında etkili olan karakteristik bir özelliktir. Başka bir deyişle öğrenme stilleri, bireylerin bilgi ve beceriye ulaşmak için tercih ettikleri yol olarak ifade edilmektedir (Pritchard, 2008). Öğrenmede önemli bir yeri olan öğrenme stilleri gerek öğrenenler gerekse eğitimciler açısından bilinmesi gereken bir alandır (Boydak, 2008). Çünkü öğrenme stilleri, öğrenenlerin bilgiyi alma ve işleme sürecinde kişisel tercihleri doğrultusunda öğrenmelerini gerçekleştirmesidir (Litzinger, Lee, Wise ve Felder, 2007). Daha genel bir ifade ile öğrenme stillerinin "bireye özgü öğrenme yolu" olduğu söylenebilir (Bilasa, 2013). Öğrenme stili bireyin yaşamında önemli bir yere sahiptir. Birey kendi öğrenme stilini bildiğinde, öğrenme sürecinde bu stili devreye sokacağı düşünülmektedir. Birey bu sayede, hem daha kolay hem de daha çabuk öğrenecek ve büyük bir olasılıkla öğrenme sürecinde başarılı olacaktır (Biggs, 2001). Dolayısıyla öğrenenler dışsal bilgi ya da içsel bilgi ve tecrübelere ulaşmak için istedikleri süreci izleyebileceklerdir (Hsieh, Jang, Hwang veChen, 2011).

Öğrenme stilleri öğrenenlerin nasıl algıladıklarından, nasıl düşündüklerinden, nasıl ezberlediklerinden ve öğrenme ile nasıl etkileşime girdiklerinden etkilenmektedir (Smutz, 2003). Bu bağlamda birey için benimsediği öğrenme stilini bilmek, bireyin öğrenme ortamlarından daha etkili bir şekilde yararlanmasına yardımcı olacaktır. Ayrıca bireyin ilgisini ortaya koyacak ve motive edecektir (Şahinel, 2011). Bunun dışında uygun yöntemlerle verimli öğrenmeyi sağlayarak bireyin daha hızlı, pratik ve kendine uygun çalışma alışkanlıkları kazanmasını, öğrenmeye karşı olumlu tutum geliştirmesini ve kendini tanımasını sağlayacaktır. Bireylerin öğrenmede başarılı olmaları kendi bilişsel süreçlerinin bilincine varabilmeleri ile olanaklıdır. Bu kapsamda da bireylerin kendi öğrenme stilini bilmesi önemlidir. Kendi öğrenmesinin farkında olan bireyler hem akademik hem de günlük yasamda başarılı olabilecektir (Güven, 2004). Mangino ve Griggs (2003) tarafından yapılan araştırmaya göre öğrenciler öğrenme stillerine göre eğitim aldıklarında akademik başarılarının istatistiksel olarak arttığı görülmektedir.

Öğrenme stiliyle ilgili alan yazında birçok sınıflama bulunmaktadır. Keefe (1990) öğrenme stilini, öğrencinin karakteristiği aynı zamanda öğretme stratejisi olarak tanımlamıştır. Öğrenme stili, öğrenci karakteristiği çerçevesinde bir öğrencinin nasıl öğrendiğini ve nasıl 
öğrenmekten hoşlandığını ifade etmektedir. Dunn ve Dunn (1993) öğrenme stilini her bireyde farklıık gösteren, bireyin yeni ve zor bir bilgi üzerine odaklanması ile başlayan bilgiyi alma ve belleğe yerleştirme işlemleriyle devam eden bir yol olarak ifade etmiştir. Kolb (1984) ise öğrenme stilini bilgiyi algılama ve işlemede kişisel olarak tercih edilen yöntem olarak ifade etmiştir. Kolb’un bu ifadesi öğrenme stilinin bir yönüyle duyusal, başka bir yönüyle de zihinsel özellikler taşıdığını ifade etmektedir. Kolb (1984) öğrencileri 4 farklı öğrenme stiline göre sınıflamaktadır. Sınıflamayı yaparken öğrencilerin bilgiyi algılama, işleme boyutlarını göz önünde tutmakta ve öğrencileri ayrıştıran, değiştiren, özümseyen ve yerleştiren olmak üzere 4 grupta sınıflamaktadır. Gregorc'un öğrenme stili modeline göre de bireylerin zihinsel nitelikleri somut sıralı, soyut sıralı, somut rastlantısal ve soyut rastlantısal olmak üzere dört farklı kategoride incelenmektedir (Bilasa, 2013). Gregorc'a göre her birey farklı miktarlarda bu dört kategoriye sahiptir. Ancak bu kategoriler bireyden bireye farklılık göstermektedir. Bu modele göre her bireyin öğrenme yeteneklerinin farklı olduğu ve bu durumun kişisel özelliklerin belirlenmesinde en önemli faktör olduğu vurgulanmaktadır (Ekici, 2013). Belirtilen öğrenme stillerinin dışında Witkin, Myers-Brigs, McCarthy, Felder-Silverman, Herman-Honey ve Mumford öğrenme stilleri modelleri de bulunmaktadır (Ekici, 2004).

Öğrenme stillerini dikkate alarak yapılan uygulamalar ve deneysel çalışmalar incelendiğinde en çok kullanılan stillerden birinin sözel-görsel ayrımı olduğu görülmektedir. Pallapu (2007) görsel ve sözel öğrenme stillerinin öğrenme üzerine etkilerini incelediği çalışmasında, öğrenme stillerinin akademik başarıyı etkilediğini ve öğretim ortamının tasarımında öğrenme stilinin dikkate alınması gerektiğini belirtmiştir. Plass ve diğerleri (1998) görsel ve sözel öğrenme üzerine yaptığı deneysel çalışmada öğrenenlerin öğrenme stilleri ile öğrenme tercihlerinin tutarlı ve ilişkili olduğunu ifade etmişlerdir. Özellikle öğretim tasarımı ve çoklu ortam tasarımı çalışmalarında sözel-görsel ayrımına göre öğelerin daha kolay tasarlanması ve hazırlanması bu değişkenlerin daha çok ele alınmasına neden olmaktadır. Bilginin görsel olarak sunulması ile öğrenmeyi daha iyi gerçekleştiren bireyler görsel öğrenme stiline sahip olan bireylerdir. Bu bireyler görsel uyarıcılardan hoşlanmakta, görsel uyarıcıları tercih etmekte ve öğretmenin beden dilini, jest ve mimiklerini görmek bireylerin konuyu anlamalarına yardımcı olmaktadır (Oral ve Avanoğlu, 2011). Görsel öğrenme stiline sahip öğrenenler görerek öğrenmektedir ve onlar için önemli olan renkler ve görüntülerdir (Bilasa, 2013). Görsel öğrenme stiline sahip bireylerin diğer özellikleri şu şekildedir (Demirel, Erdem, ve Başbay, 2006): 
- Duydukları yönergelerden çok gördüklerine dikkat ederler.

- Sözel tariflerin tekrar edilmesini isterler.

- Sözcüklerin ağızdan dökülüşünü izlerler.

- Sözleri kolay hatırlayamazlar, ancak görüntüler zihinlerinde kolayca canlanabilirler.

- Insanların davranışlarını gözlemlerler.

- Anlatılanları zihinlerinde canlandırırlar.

Sözel öğrenme stiline sahip öğrenenler sözel öğelere yatkınlık göstermektedir. Bu öğrenenler seslere, kelimelere (sözcüklere) duyarlıdır ve konuşmayı çok severler (Bilasa, 2013). Literatürde sözel öğrenme stilinin özellikleri şu şekilde ifade edilmektedir (Felder ve Silverman, 1988; Felder 1993, 1996; Felder ve Solomon, 1998, Felder ve Henriques 1995):

- En çok yazılı ve sözlü uyaranları ve söylenenleri hatırlarlar.

- Tartışmaları, sözel ifadeleri görsel sunumlara tercih ederler ve bir şeyi başkalarına kelimelerle ifade ederek en etkin biçimde öğrenirler.

- Bilgileri sözel olarak kodlamaya yatkındırlar.

- Görsel uyaranları anlama ve kodlamada sıkıntı yaşayabilirler.

- Okuma ve tekrardan başka bilgiyi kodlama stratejilerini pek bilmediklerinden dolayı, öğrenme stratejilerinde farklılıkları benimsemezler.

Sözel ve görsel öğrenme stili farklılı̆ının öğrenme-öğretme süreçlerinde dikkate alınabilmesi için öncelikle öğrencinin baskın öğrenme stilinin bunlardan hangisi olduğunu belirlemek gereklidir. Sözel ve görsel öğrenenlerin farklııklarının ortaya konduğu ilk çalışmada kullanılan veri toplama araçlarından biri "Santa Barbara Learning Style" ölçeğidir (The Santa Barbara Learning Style Questionnaire - SBLSQ) (Wang, 2007). Altı maddeden oluşan ölçekte sözel-görsel bilişsel stil değerlendirilmektedir. Ölçekle birlikte görüşme yoluyla veri toplanan çalışmada, görsel ve sözel öğrenenlerin öğrenme yolları araştırılmaya çalışılmıştır. Bu çalışmayla iki grubun nasıl algıladıkları, nasıl ezberledikleri ve nasıl düşündükleri incelenmiştir. Çalışmada, görsel öğrenenlerin puanlarının sözel öğrenenlerin puanlarından yüksek olduğu görülmüştür. Ayrıca, öğrenme performansının öğretmen ve öğrenenlerin sözel-görsel bilişsel stilleri ile ilişkili olduğu sonucuna ulaşılmıştır (Wang, 2007). Şimşek (2002) öğrenme biçimlerine dönük geliştirmiş olduğu envarterde 16-25 yaş arası bireylerin öğrenme biçimlerini belirlemeyi amaçlamıştır. 256 üniversite öğrencisi ile envanterin geçerliliği ve güvenirliliğine yönelik bir çalışma yapmıştır. Öğrenme biçimlerini görsel, işitsel ve bedensel olarak ayırarak envanterde yer vermiştir. Kolb ve Myers-Briggs'in çalışmalarını temel alan Felder ve Solomon Öğrenme Stili 
Envanteri (1996) öğrenme stillerini sıralı/bütüncül (sequential-global), aktif/yansıtııı (activereflective), duyusal/sezgisel (sensory-intuitive) ve görsel/sözel (visual/verbal) olmak üzere dört boyutta ele almaktadır. Görsel öğrenme biçimine yatkın olanların en iyi resimler ve çizimlerle öğrenirken, sözel öğrenme biçimine yatkın olanların yazılı veya sözlü açıklamaları tercih ettiği ifade edilmektedir. Kütüphanecilik ve bilgi bilim alanında okuyan 56 öğrenci üzerinde Felder ve Solomon Öğrenme Stili Envanteri kullanılarak gerçekleştirilen çalışmanın sonucunda öğrencilerin görsel öğrenme biçiminin sözelden ağır bastığı görülmüştür (Adkins ve BrownSyed, 2002).

Childers, Houston ve Heckler (1985) tarafından görsel-sözel öğrenme stillerini inceleyen bir ölçek (Style of Processing Scale-SOP) geliştirilmiştir. Bu öğrenme stilleri ölçeği, öğrencilerin görsel ve sözel bilgi işlem yöntemi tercihlerini ve bu işlemleri kullanma eğilimlerini değerlendirmek amacıyla yaygın olarak kullanılmaktadır (Lightner ve Eastman, 2002). Townsend ve Kahn (2014) SOP’u kullandıkları çalışmalarında ürün çeşitliliğinde görsel bilgilerin mi ya da sözel bilgilerin mi tüketiciler tarafından daha çok tercih edilip edilmediğini araştırmışlardır. Araştırma sonuçlarına göre görsel bilgi içeren ürünlerin sözel bilgi içeren ürünlere göre daha çok algısal çeşitlilik sağladığı, görsel sunumların daha kolay hissedildiği görülmüştür. SOP ölçeğinin kullanıldığı bir diğer çalışmada e-ticaret sitelerinde ürün bilgilerinin verilmesinde cümlesel açıklamaların daha çok tercih edildiği sonucuna ulaşılmıştır (Lightner ve Eastman, 2002). Heckler, Childers ve Houston (1993) SOP ölçeğini yeniden düzenleyerek beşli likert tipli ve 20 maddelik (10 madde görsel, 10 madde sözel) bir ölçek geliştirmişlerdir. Bu ölçek 883 üniversite öğrencisine uygulanmış ve iç tutarlılık katsayısı (Cronbach alpha değeri) ,83 olarak bulunmuştur (Liu, Kinshuk, Lin ve Wang, 2012). Liu ve diğerleri (2012) bu uyarlama ölçeğini kullandıkları çalışmalarında benzetim temelli bilgisayar destekli öğretim sistemlerine yönelik olarak 25 katılımcı ile deneysel bir araştırma gerçekleştirmiştir. Araştırmanın sonucuna göre benzetim temelli bilgisayar destekli öğretim sistemlerinde öğrenme performansları açısından sözel ve görsel öğrenme stillerine sahip öğrenciler arasında anlamlı farklılık bulunmamıştır. Benzer şekilde SOP ölçeğinin kullanıldığı birçok çalışma bulunmaktadır (Chen ve Sun, 2012; Wyer Jr., Hugn ve Jiang, 2008; Wong, Rindfleisch, Burroughs, 2003; Sun ve Chen, 2010; Best, Stewart ve McGuire, 2008; Darley, 1999).

Alan yazına bakıldığında sözel-görsel öğrenme stili ayrımının önemli bir ayrım olduğu vurgulanmakta hem çoklu ortam ve öğretim tasarımında hem de öğrenme-öğretme süreçlerinde dikkate alınması gerektiği görülmektedir. Türkiye'de yapılan çalışmalar 
incelendiğinde doğrudan sözel-görsel öğrenme stilini belirlemeye yönelik bir ölçeğe rastlanılmamıştır. Rastlanılan çalışmalardaki ölçeklerin öğrenme stillerinin farklı boyutlarını incelediği görülmüştür. Bu ölçeklerden Gregorc Öğrenme Stili Ölçeği'nin Ekici (2002) tarafından Türkçeye uyarlaması yapılmıştır. Bu ölçeğe göre kişiler soyut ve somut algılayanlardır ve algılama becerilerine göre öğrenme durumları onların öğrenme stillerini oluşturur (Ekici, 2013). Kolb Öğrenme Stili Envanteri'nin, Aşkar ve Akkoyunlu (1993) tarafından Türkçeye uyarlaması yapılmıştır. Bu modele göre bireylerin baskın öğrenme stili değiştiren, özümseyen, ayrıştıran veya yerleştiren olarak belirlenmektedir (Çelik ve Şahin, 2011; Okur, Bahar, Akgün, ve Bekdemir, 2011). Ancak Kolb Öğrenme Stili Envanteri ilköğretim 6., 7. ve 8. sınıflar için uygun olmadığı yetişkinler için uygun olduğu belirtilmiştir (Koçak, 2007). Alan yazında Aşkar ve Akkoyunlu tarafından uyarlanan ölçeğin kullanıldığı birçok çalışmaya rastlanılmaktadır (Ateş ve Altun, 2008; Demir, 2006; Arslan ve Babadoğan, 2005). Gökdağ (2004) tarafından da bir Öğrenme Stilleri Ölçeği geliştirilmiştir. Tamamı olumlu cümlelerden oluşan 28 maddelik ölçek, görsel (13 madde), işitsel (5 madde) ve hareketsel (10 madde) olmak üzere üç faktörden oluşmaktadır (Gökdağ, 2004). Gökdağ’ın Öğrenme Stilleri Ölçeği ile bireylerin hangi öğrenme stiline yatkın olduğundan çok ne zaman hangi öğrenme stilini daha baskın kullandıkları incelenmektedir (Gökdağ, 2004; Eskici, 2008). Benzer şekilde 23 maddeden oluşan ve görsel öğrenme boyutu ( 8 madde), işitsel öğrenme boyutu (7 madde) ve kinestetik-dokunsal öğrenme boyutu (8 madde) faktörlerinden oluşan Öğrenme Stilleri Envanteri Ersoy (2003) tarafından geliştirilmiştir. Güven ve Özbek tarafından 27 madde ve 8 faktörden oluşan Öğrenme Stili Envanteri geliştirilmiştir (Güven ve Özbek, 2007). Bu envanterde 6-14 yaş aralığındaki öğrencilerde öğretimi bireyselleştirmek için gerçekleştirilecek etkinliklerde öğrencilerin özelliklerinin ortaya çıkarılması hususunda sınıf öğretmenlerine yardımcı olması amaçlanmıştır (Güven, 2008). Öğrenenlerin sosyal öğrenme seçimlerini; bağımsız, pasif, işbirlikçi, bağımlı, rekabetçi ve katılımcı olarak altı kategoride inceleyen Grasha-Reichmann Öğrenme Stili Ölçeği Koçak (2007) tarafından Türkçeye uyarlanmış ve 42 maddelik bir ölçek haline getirilmiştir. Tüm bu çalışmalar incelendiğinde sözel ve görsel öğrenme stillerinden baskın olanı doğrudan ve pratik olarak belirleyecek bir ölçeğin bulunmadığı görülmektedir. Bununla birlikte Polat, Adıgüzel ve Akgün'ün (2012) yaptıkları araştırmanın sonuçlarına göre özel öğrenme güçlüğü yaşayan öğrencilerin görsel ve sözel stillerini dikkate alarak bireyselleştirilmiş öğretim sağlayacak uyarlanabilir ve destekleyici sistemlerin uygulamaya konulabilmesi için sözel ve görsel baskın stili belirleyecek ölçme araçlarına ihtiyaç duyulmaktadır. Bu nedenle bu 
çalışmanın amacı Childers, Houston ve Heckler (1985) tarafından geliştirilen ve yaygın hale gelen Öğrenme Stilleri Ölçeğini (Style of Processing Scale - SOP) Türkçeye uyarlamaktır.

\section{YÖNTEM}

Bu çalışma, bir ölçek uyarlama çalışmasıdır. Ölçeğin uyarlanması için gerekli izin e-posta yolu ile alınmıştır. Ölçeğin Türkçeye uyarlama çalışmaları çerçevesinde, ilk olarak özgün ölçekteki maddeler araştırmacılar tarafından Türkçeye çevrilmiştir. Araştırmacılar tarafından yapılan çeviriden sonra özgün maddeleri, çevrilen maddeleri ve yapılacak uzman önerisini içeren bir form uzmanlara görüş almak için dağıtılmıştır. Uzman görüşü için İngilizce Eğitimi (3), Türkçe Eğitimi (1), Bilgisayar ve Öğretim Teknolojileri Eğitimi (BÖTE) (1), Ölçme ve Değerlendirme Eğitimi (1) ve Eğitim Bilimleri (4) alanında çalışan akademisyenlere başvurulmuştur. Uzmanlardan gelen görüşler doğrultusunda gerekli düzeltmeler yapılmış ve Türkçe maddelere ulaşılmıştır. Bu işlemin ardından Türkçe maddelerin anlaşılırlığı 3 üniversite öğrencisi ile görüşülerek incelenmiştir. Özgün ölçekteki maddeler ile Türkçe ölçekteki maddeler arasındaki eşdeğerliğin kontrolü için İngilizce ve Türkçe formlar bir hafta arayla iki dili de çok iyi bilen ve kullanan 17 kişiye uygulanmıştır. İngilizce ve Türkçe formların uygulandığı kişilerin tamamı üniversitelerde İngilizce okutman ve çevirmen kadrolarında görev yapmakta olup yaşları 24-27 aralığında bulunmaktadır. İki formdan elde edilen puanlar arasında Pearson momentler çarpımı korelasyon katsayısı hesaplanarak, değerin 0.94 olduğu bulunmuştur. Bu bulgu ölçeğin İngilizce ve Türkçe formlarının eşdeğer kabul edilebileceğini göstermektedir.

\subsection{Katılımcılar}

Araştırmanın katılımcılarını, 2012-2013 öğretim yılında Bartın Üniversitesi Eğitim Fakültesinde öğrenim gören ve araştırmaya gönüllü olarak katılan 240 öğretmen adayı oluşturmaktadır. Çalışmaya katılan öğrencilerin, 80'i sınıf öğretmenliği eğitimi (33.3), 79'u fen bilgisi eğitimi (32.9), 44'ü sosyal bilgiler eğitimi (18.3) ve 37'si matematik eğitimi (15.4) anabilim dallarında öğrenim görmektedir.

\subsection{Veri Toplama Aracı}

Öğrenme Stilleri Ölçeği, Childers, Houston ve Heckler tarafından 1985 yılında geliştirilmiştir. Childers ve diğerleri yaptıkları çalışmada, VVIQ (Marks, 1973), VIC (Richardson, 1969), VVQ (Richardson, 1977) ölçeklerindeki düşük iç tutarlılık ve güvenirlik sebebiyle psikometrik özellikleri daha iyi olan bir öğrenme stili ölçeği olan Bilgiyi İşleme Stili (BiS) ölçeğini geliştirmeye karar vermişlerdir. Bis ölçeği, sözel ve görsel olmak üzere 2 ayrı alt ölçekten oluşmaktadır. Özgün ölçekte sözel ve görsel alt ölçeklerin her birinde 11 madde olup özgün 
ölçek toplamda 22 maddeden oluşmaktadır. Ölçeklerde yer alan maddeler için 4'lü Likert tipi dereceleme kullanılmıştır. Bu dereceleme, "Benim için her zaman doğru (1), Benim için genellikle doğru (2), Benim için genellikle yanlış (3), Benim için her zaman yanlış (4)" şeklinde oluşturulmuştur. Ölçekten alınan düşük puan öğrencinin sözel öğrenme stiline, yüksek puan ise görsel öğrenme stiline sahip olduğunu göstermektedir. Orijinal ölçeklerin geçerlik ve güvenirlik çalışmaları, Midwestern Üniversitesinde öğrenim gören 104 öğrenciden elde edilen veriler ile gerçekleştirilmiştir. Özgün ölçeğin yapı geçerliliği, doğrulayıcı faktör analizi ile incelenmiştir. Analiz, ölçeğin sözel ve görsel alt ölçekleri için ayrı ayrı yapılmış ve sonuçlar ölçeğin faktör yapısına ilişkin önerilen modelin geçerli olduğunu göstermiştir. Özgün ölçekteki faktörlerin güvenirliği Cronbach alfa katsayısısı ile incelenmiştir. Özgün ölçeğin, görsel alt boyutu için Cronbach Alfa iç tutarlıık katsayısı .81, sözel alt boyutu için Cronbach alfa iç tutarlılık katsayısı ise .86 olarak bulunmuştur.

Ölçekten elde edilen verilere yapı geçerliliği için doğrulayıcı faktör analizi uygulanmıştır. Doğrulayıcı faktör analizi (DFA), önceden belirlenen ya da kurgulanan bir modelin elde edilen verilerle ne derece doğrulandığını incelemeyi amaçlamaktadır (Büyüköztürk, Akgün, Özkahveci ve Demirel, 2004). Bu sebeple, ölçeklerin Türkçe uyarlamasının yapıldığı bu araştırmada, 240 öğretmen adayından elde edilen verilerle doğrulayıcı faktör analizi yapılarak ölçeklerin yapı geçerliliği test edilmiştir. Bu çalışmada yapılan analizlerde Lisrel 8.7 programı kullanılmıştır. Ayrıca, ölçeklerin Cronbach alfa iç tutarlılık katsayıları, düzeltilmiş madde toplam korelasyon değerleri ve alt \% 27 ve üst \%27'lik grupların madde toplam korelasyon puanları hesaplanmıştır.

\section{BULGULAR}

\subsection{Doğrulayıcı Faktör Analizi Sonuçları:}

Özgün ÖSP ölçeğinin belirtilen faktör yapısı, Türk uzmanlarca da kabul gördüğünden ölçeğin yapı geçerliği doğrulayııı faktör analizi (DFA) ile sınanmıştır. İlk olarak özgün ölçekte belirtilen iki faktörlü model için uyum istatistikleri hesaplanmıştır. Analiz sonucunda Ki-Kare $\left(x^{2}=457.26, p=.000, s d=208, x^{2} / s d=2.19\right)$ değeri başta olmak üzere uyum indekslerinin $(\mathrm{RMR}=0.08, \mathrm{GFI}=0.85, \mathrm{AGFI}=0.82, \mathrm{RMSEA}=0.071, \mathrm{NNFI}=0.79, \mathrm{CFI}=0.81$ ), modelin çok iyi uyum göstermediğine işaret etmektedir. Illk analiz sonuçları incelendiğinde modifikasyon indekslerinin önemli bir değişiklik önermediği dikkat çekmektedir. Sadece 10. Madde ile 20 madde arasında yüksek hata kovaryansı olduğu görülmektedir. Bu maddeler incelendiğinde, 20. maddenin 10. Madde ile aynı özelliği ölçtüğü sadece ters madde olduğu ve standardize 
edilmiş katsayısının daha düşük olduğu görüldüğünden görsel ölçekten 20. maddenin uzman görüşü alınarak atılmasına karar verilmiştir. T değerlerine bakıldığında sözel ölçekten 3. ve 18. maddelerin değerlerinin anlamsız olduğu ve bu maddelerin gizil değişkenlerle aralarındaki standardize edilmiş katsayılarının çok düşük (sırasıyla $0.07,0.12$ ) olduğu görülmüştür. Uzman görüşü alınarak bu maddelerin ölçekten çıkarılmasına karar verilmiştir. Modelde standardize edilmiş katsayıları düşük başka maddeler de (14 ve 19) bulunmaktadır ancak öncelikle yukarıda belirtilen maddeler atılarak model yeniden incelenmiştir.

İkinci analiz sonucunda ise $\mathrm{x}^{2} / \mathrm{sd}=1.94$ değeri başta olmak üzere uyum indeksleri $\mathrm{RMR}=0.074, \mathrm{GFI}=0.89, \mathrm{AGFI}=0.86, \mathrm{RMSEA}=0.063, \mathrm{NNFI}=0.86, \mathrm{CFI}=0.88$ olarak belirlenmiş olup, t testi değerlerinin tümünün anlamlı olduğu görülmektedir. Ancak standardize edilmiş katsayılar incelendiğinde 14 madde (0.17) ve 19 madde (0.14) değerlerinin gizil değişkenle aralarındaki standardize edilmiş katsayısının çok düşük olduğu görülmüştür. Bu nedenle sözel ölçekte yer alan ve katsayısı daha düşük olan 19. madde uzman görüşü alınarak ölçekten çıkarılmış ve analiz yinelenmiştir.

Üçüncü analiz sonucu incelendiğinde, $x^{2} / s d=1.77$ değeri başta olmak üzere uyum indekslerinin RMR=0.068, GFI=0.90, AGFI=0.87, RMSEA=0.057, NNFI=0.89, CFI=0.91 olduğu görülmektedir. Bu analize göre görsel ölçekteki 12. madde ve 14. maddenin gizil değişkenle standardize edilmiş katsayı değerlerinin beklenenin çok altında olduğu görülmüş (sırasıyla 0.23, 0.17) ve bu maddeler uzman görüşü de alınarak ölçekten çıkarılmıştır.

Dördüncü analiz sonuncunda ise $x 2 / s d=1.71$ değeri başta olmak üzere uyum indekslerinin $\mathrm{RMR}=0.063, \mathrm{GFI}=0.92, \mathrm{AGFI}=0.89, \mathrm{RMSEA}=0.055, \mathrm{NNFI}=0.92, \mathrm{CFI}=0.93$ kabul edilebilir olduğu görülmektedir (Tablo 1). Şekil 1' de görüldüğü gibi modele ilişkin standardize edilmiş katsayı değerleri 0.27 (madde 9 ve 4) ve 0.79 (madde 17) arasında yer almakta olup, anlamlı düzeydedir ( $p<.05)$ (Şekil 1). 
Sözel veya Görsel Baskın Öğrenme Stilini Belirleme Ölçeği Türkçe Formunun Geçerlik... Özcan Erkan AKGÜN - Şirin KÜÇÜK - Barış ÇUKURBAŞI - İsmail TONBULOĞLU

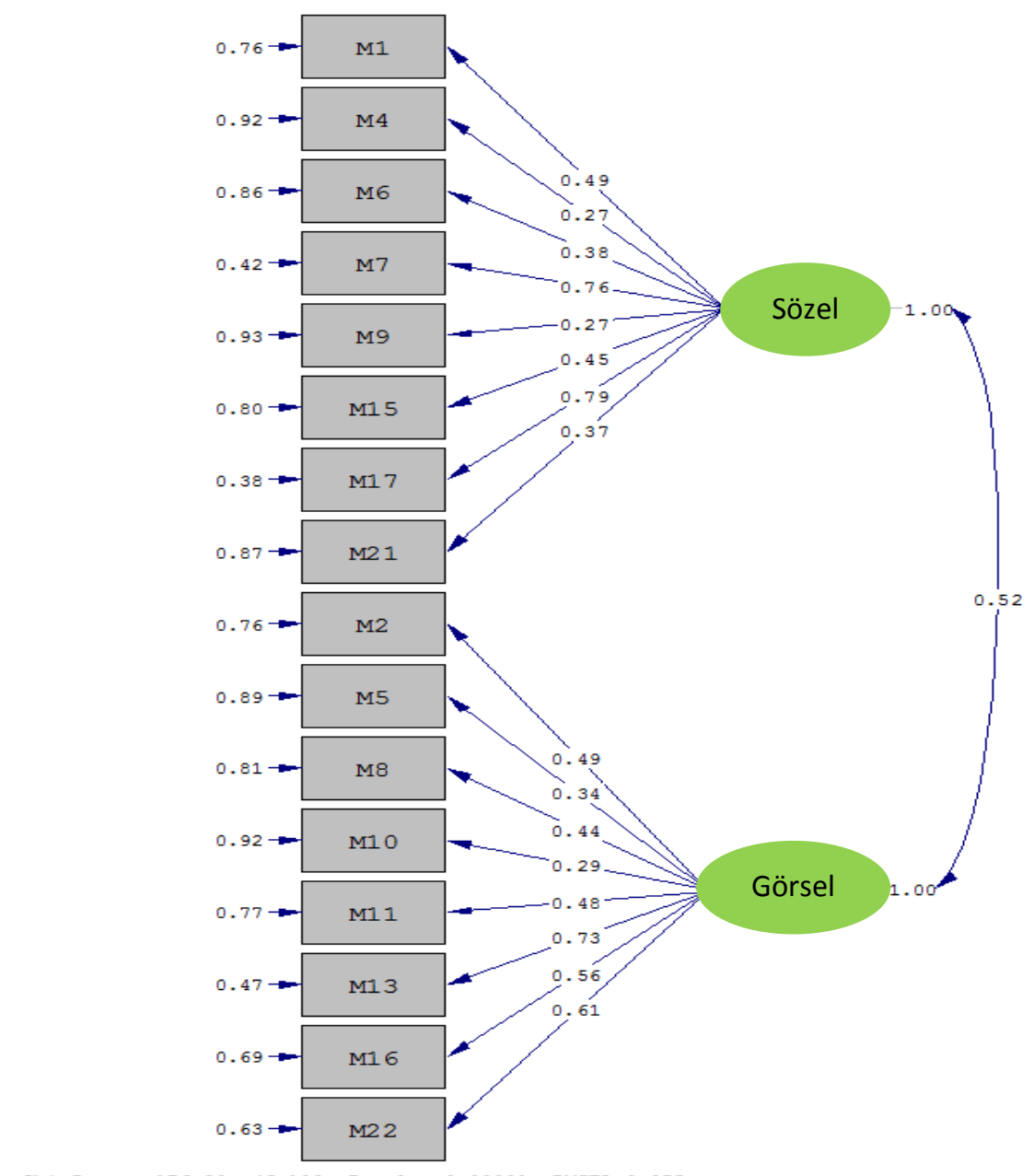

Chi-Square $=176.20, \mathrm{df}=103, \mathrm{P}-\mathrm{value}=0.00001, \mathrm{RMSEA}=0.055$

Şekil 1. Öğrenme Stilleri Ölçeğine Iliş̧kin Yol Diyagramı ve Standardize Edilmiş Katsayı Değerleri

Tablo 1. Öğrenme Stilleri Ölçeğinin Uyum İndeksleri Değerleri ve Uyum İndekslerinin

Kabul Değerleri (Schermelleh-Engel, Moosbrugger, ve Müller, 2003; Meydan ve Şeşen, 2011)

\begin{tabular}{cccc}
\hline \multirow{2}{*}{ Uyum Indeksleri } & íyi Uyum & Kabul Edilebilir Uyum & $\begin{array}{c}\text { Öğrenme Stilleri } \\
\text { Değlçeği }\end{array}$ \\
\cline { 3 - 4 } & & & Türkçe \\
\hline$\chi^{2} / \mathrm{sd}$ & $0 \leq \chi^{2} / \mathrm{df} \leq 2$ & $2<\chi^{2} / \mathrm{df}<3$ & 1.71 \\
\hline $\mathrm{RMSEA}$ & $0 \leq \mathrm{RMSEA} \leq .05$ & $.06 \leq \mathrm{RMSEA} \leq .08$ & 0.05 \\
\hline $\mathrm{GFI}$ & $.95 \leq \mathrm{GFI} \leq 1.00$ & $.90 \leq \mathrm{GFI}<.95$ & 0.92 \\
\hline $\mathrm{AGFI}$ & $.90 \leq \mathrm{AGFI} \leq 1.00$ & $.85 \leq \mathrm{AGFI}<.90$ & 0.89 \\
\hline $\mathrm{NNFI}$ & $.95 \leq \mathrm{NNFI}$ & $.94 \leq \mathrm{NNFI}<.90$ & 0.92 \\
\hline $\mathrm{CFI}$ & $.95 \leq \mathrm{CFI}$ & $.94 \leq \mathrm{CFI}<.90$ & 0.93 \\
\hline $\mathrm{RMR}$ & $\mathrm{RMR} \leq .0 .05$ & $0.06 \leq \mathrm{RMR} \leq 0.08$ & 0.063 \\
\hline
\end{tabular}


DFA ile sınanan modelin uyum indeksleri incelendiğinde Ki-Kare değerinin $\left(\chi^{2}=176.28\right.$, $s d=103, p=.000$ ) anlamlı olduğu görülmektedir. Uyum indeksi değerleri ise, RMSEA=0.055, $\mathrm{GFI}=0.92, \mathrm{AGFI}=0.89, \mathrm{CFI}=0.93, \mathrm{NNFI}=0.92, \mathrm{RMR}=0.063$ ve $\mathrm{RMR}=0.063$ 'dür (bkz. Tablo 1 ). $\mathrm{x}^{2} / \mathrm{df}$ ve RMSEA değerlerinin iyi uyum gösterdiği; GFI, AGFI, NNFI, CFI ve RMR değerlerinin ise kabul edilebilir uyum gösterdiği görülmektedir.

Tablo 2. Öğrenme Stilleri Ölçeğinin Doğrulayıcı Faktör Analizi t değerleri

\begin{tabular}{|c|c|c|c|c|c|c|c|}
\hline \multirow[b]{2}{*}{ Faktör } & \multicolumn{7}{|c|}{ Öğrenme Stilleri Ölçeği } \\
\hline & Madde No & \multicolumn{2}{|c|}{ t değeri } & Faktör & Madde No & \multicolumn{2}{|c|}{ t değeri } \\
\hline \multirow{9}{*}{ 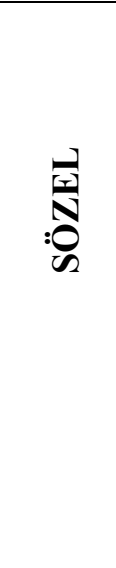 } & & Türkçe & Özgün & \multirow{9}{*}{ 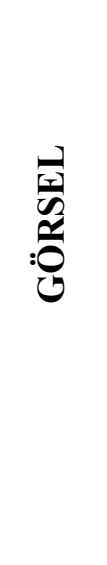 } & & Türkçe & Özgün \\
\hline & 1 & 7.26 & 4.05 & & 2 & 7.13 & 4.96 \\
\hline & 4 & 3.90 & 4.88 & & 5 & 4.74 & 3.29 \\
\hline & 6 & 5.48 & 2.95 & & 8 & 6.25 & 4.25 \\
\hline & 7 & 12.26 & 5.20 & & 10 & 4.01 & 4.10 \\
\hline & 9 & 3.82 & 1.47 & & 11 & 6.92 & 3.56 \\
\hline & 15 & 6.60 & 4.59 & & 13 & 11.30 & 7.14 \\
\hline & 17 & 12.78 & 5.30 & & 16 & 8.27 & 7.22 \\
\hline & 21 & 5.30 & 6.29 & & 22 & 9.14 & 7.77 \\
\hline
\end{tabular}

Yapılan analizler sonucunda sözel ölçekten 3, 18, 19. maddeler ve görsel ölçekten ise 12, 14, 20. maddeler olmak üzere toplamda 6 madde öğrenme stilleri ölçeğinden atılmıştır. Türkçeye uyarlaması yapılan öğrenme stilleri ölçeğinin alt boyutlarından sözel ölçeğin 8 maddeden $(1,4,6,7,9,15,17,21)$ ve görsel ölçeğin ise 8 maddeden $(2,5,8,10,11,13,16,22)$ olmak üzere toplam 16 maddeden oluştuğu görülmektedir (Şekil 1) (Ek-1).

\subsection{Madde Analizine Yönelik Bulgular:}

Ölçekte yer alan maddelerin kişileri ne derece ayırt ettiğini incelemek amacıyla düzeltilmiş madde toplam korelasyonları hesaplanmış ve üst \%27 ile alt \%27 grupların madde ortalama puanları arasındaki farkların anlamlılığı için t-testi yapılmıştır. Analiz sonuçları Tablo 3 ile gösterilmiştir. 
Sözel veya Görsel Baskın Öğrenme Stilini Belirleme Ölçeği Türkçe Formunun Geçerlik... Özcan Erkan AKGÜN - Şirin KÜÇÜK - Barış ÇUKURBAŞI - İsmail TONBULOĞLU

Tablo 3. Öğrenme Stilleri Ölçeği Faktörlerinin Düzeltilmiş Madde Toplam Korelasyonları ve Üst \%27, Alt \%27 Puanları Arasındaki ilişkisiz t testi Sonuçları

\begin{tabular}{|c|c|c|c|c|c|c|c|}
\hline Faktör & $\begin{array}{c}\text { Madde } \\
\text { No }\end{array}$ & $\begin{array}{c}\text { Düzeltilmiş } \\
\text { Madde- } \\
\text { Toplam } \\
\text { Korelasyonu }\end{array}$ & $\begin{array}{c}\text { t } \\
\text { (üst \%27- } \\
\text { alt \%27)* }\end{array}$ & Faktör & $\begin{array}{c}\text { Madde } \\
\text { No }\end{array}$ & $\begin{array}{c}\text { Düzeltilmiş } \\
\text { Madde- } \\
\text { Toplam } \\
\text { Korelasyonu }\end{array}$ & $\begin{array}{c}\mathrm{t} \\
\text { (üst \%27- } \\
\text { alt \%27)* }\end{array}$ \\
\hline \multirow{8}{*}{ Oే } & 1 & .43 & $-4.04^{*}$ & \multirow{8}{*}{$\begin{array}{l}\frac{1}{0} \\
0 \\
0 \\
0 \\
0\end{array}$} & 2 & .39 & $-8.79 *$ \\
\hline & 4 & .29 & -1.93 & & 5 & .27 & $-7.96^{*}$ \\
\hline & 6 & .31 & $-2.68^{*}$ & & 8 & .34 & $-9.51^{*}$ \\
\hline & 7 & .50 & $-4.89 *$ & & 10 & .25 & $-7.72^{*}$ \\
\hline & 9 & .27 & $-4.47^{*}$ & & 11 & .42 & $-8.38^{*}$ \\
\hline & 15 & .35 & $-4.01 *$ & & 13 & .59 & $-11.40^{*}$ \\
\hline & 17 & .57 & $-4.71^{*}$ & & 16 & .44 & $-11.06^{*}$ \\
\hline & 21 & .38 & -1.72 & & 22 & .49 & $-12.53^{*}$ \\
\hline
\end{tabular}

$*(p<.01)$

Sözel ölçeğin, düzeltilmiş madde-toplam korelasyon değerleri .27 ile .57 arasında değişmektedir. Üst \%27 ile alt \%27'lik grubun puanları arasında yapılan t testi sonuçlarına göre 4. ve 21.maddelerin dışında diğer tüm maddeler için anlamlı bir farklııı olduğu görülmektedir ( $p<.01)$. Görsel ölçeğin ise düzeltilmiş madde-toplam korelasyon değerleri .25 ile .59 arasında değişmektedir. Üst \%27 ile alt \%27'lik grubun puanları arasında yapılan $t$ testi sonuçları tüm maddeler için anlamlı bir farklılık olduğunu göstermektedir $(p<.01)$.

\subsection{Güvenirliğe Yönelik Bulgular:}

Türkçeye uyarlaması yapılan öğrenme stilleri ölçeğinde yer alan boyutların güvenilirliklerini incelemek amacıyla Cronbach alfa değerleri hesaplanmıştır. Ölçeklerin özgün ve Türkçe formları için hesaplanan alfa katsayıları Tablo 4'de verilmiştir.

Tablo 4. Öğrenme Stili Ölçeğinin Cronbach Alfa Katsayıları

\begin{tabular}{|c|c|c|}
\hline \multicolumn{3}{|c|}{ Öğrenme Stilleri Ölçeği } \\
\hline \multirow[t]{2}{*}{ Faktör Adı } & \multicolumn{2}{|c|}{ Alfa Değeri } \\
\hline & Türkçe & Özgün \\
\hline Sözel & .69 & .81 \\
\hline Görsel & .71 & .86 \\
\hline
\end{tabular}


Öğrenme stilleri ölçeğinin, alt boyutlarından biri olan sözel ölçeğin Cronbach Alfa iç tutarlılık katsayısı .69, diğer alt boyutu olan görsel ölçeğin Cronbach Alfa iç tutarlılık katsayısı ise .71 olarak bulunmuştur. Childer, Houston ve Heckler (1985) yaptıkları analizler sonucunda sözel ölçeğin Cronbach alfa değerini .81, görsel ölçeğin Cronbach alfa değerini ise .86 olarak belirtmiştir. Bulunan bu değerler, ölçeğin güvenirlik düzeylerinin ölçülen özelliğin zorluğu dikkate alındığında kabul edilebilir olduğunu göstermektedir. Türkçe ölçek formundaki değerlerin özgün ölçekteki değerlere göre düşük olmasının bir nedeni Türkçe ölçekteki madde sayısının azalması olabilir. İleride yapılacak çalışmalarda Türkçe ölçekteki çalışmayan maddelerin revize edilmesi ve bu şekilde madde sayısının artırılması dikkate alınabilir.

Ölçek Puanının Hesaplanması ve Yorumlanması

Ölçek puanının hesaplanması için öncelikle verilen yanıtlar "Benim için her zaman doğru" seçeneğine 4, "Benim için genellikle doğru" seçeneğine 3, "Benim içim genellikle yanlış" seçenğine 2 ve "Benim için her zaman yanlış" seçeneğine 1 puan verilerek kodlanır. Bunun ardından yukarıda belirtilen sözel alt faktöründe yer alan ve görsel faktöründe yer alan maddelere verilen puanlar ayrı ayrı toplanır. Bu şekilde ölçeği dolduran kişinin sözel ve görsel puanları ayrı ayrı belirlenmiş olur. Ölçeği dolduran kişinin hangi alt ölçekten daha yüksek puan aldıysa, baskın stilinin bu puan türünde görece yüksek olduğu söylenebilir. Eşit puan alınması durumunda bu iki stil açısından baskın stil belirlenememiş olur. Yapılacak araştırmalarda ve ölçeğin öğrenme-öğretme süreçlerinde kullanıldığı durumlarda her bir birey için bu iki puanın ayrı ayrı analiz edilmesi gereklidir. Bir başka deyişle ölçekten toplam tek bir puan elde edilememektedir.

\section{SONUÇ VE ÖNERILER}

Bu çalışma ile Childers, Houston ve Heckler (1985) tarafından sözel veya görsel baskın öğrenme stilini belirlemek amacıyla geliştirilen ölçek Türkçeye uyarlanmıştır. Sözel veya Görsel Baskın Öğrenme Stilini Belirleme Ölçeği, sözel ve görsel olmak üzere 2 alt ölçekten oluşmaktadır. Sözel ve görsel alt ölçeklerin her birinde 8'er madde olup ölçek toplamda 16 maddeden oluşmaktadır. Türkçeye uyarlaması yapılan ölçeğin dil eşdeğerliği sonuçları Türkçe formun özgün ölçek ile eş değer kabul edilebileceğini göstermiştir. Ölçeğin Türkçe formunun yapı geçerliğine doğrulayıcı faktör analizi ile bakıımıştır.

Yapılan dört analiz boyunca modifikasyon indeksi ve uzman görüşleri sonucunda 3, 12, 14, 18, 19 ve 20 numaralı maddeler ölçekten çıkarılmıştır. Bu sayede geçerlik açısından mevcut verilere uygun en iyi çözüme ulaşıımıştır. Modele ilişkin standardize edilmiş katsayı değerleri 
ise 0.27 (madde 9 ve 4) ve 0.80 (madde 17) arasında yer almakta olup, anlamlı düzeydedir $(p<.05)$. Bu sonuçlar ölçeğin geçerli bir yapıya sahip olduğunu ortaya koymaktadır. Doğruluğu sınanan yapının güvenilirlik analizleri yapılmıştır. Öğrenme stilleri ölçeğinin, alt boyutlarından biri olan sözel ölçeğin Cronbach Alfa iç tutarlııı katsayısı .69, diğer alt boyutu olan görsel ölçeğin Cronbach Alfa iç tutarlılık katsayısı ise .71 olarak bulunmuştur. Üst \%27 ile alt \%27'lik grubun puanları arasında yapılan $t$ testi sonuçları tüm maddeler için anlamlı bir farklılık olduğunu göstermektedir. Bu sonuca bağlı olarak ölçeğin psikolojik özelikleri ölçen araçlar açısından yeterli düzeyde güvenilir olduğu ve maddelerin iyi bir ayırt ediciliğe sahip oldukları belirtilebilir.

Araştırma sonucunda Türkçeye uyarlaması yapılan öğrenme stilleri ölçeğinin geçerli ve güvenilir olduğu ortaya çıkmıştır. Sonuç olarak sözel ölçekten 3,18 , 19. maddeler ve görsel ölçekten ise 12, 14, 20. maddeler olmak üzere toplamda 6 madde öğrenme stilleri ölçeğinden atılmıştır. Türkçeye uyarlaması yapılan öğrenme stilleri ölçeğinin alt boyutlarından sözel ölçeğin 8 maddeden $(1,4,6,7,9,15,17,21)$ ve görsel ölçeğin ise 8 maddeden $(2,5,8,10,11,13,16$, 22) olmak üzere toplam 16 maddeden oluştuğu görülmektedir. Araştırma sonucunda geçerli ve güvenilir bir ölçek ortaya çıkmıştır. Geliştirilen ölçeğin öğretme-öğrenme süreçlerinde, araştırmalarda, destekleyici ve uyarlayan sistemlerin geliştirilmesinde ve uygulanmasında kullanılması umulmaktadır. Bununla birlikte ölçek kullanıldıkça ortaya çıkacak yayınlar ve kullananların önerileri dikkate alınarak ölçeğin farkı hedef kitleler üzerinde ve daha çok katılımcı ile geliştirme çalışmalarına devam edilmesi planlanmaktadır. Ayrıca bu ölçekten elde edilen puanların öğrencileri ayırmada ne düzeyde başarılı olduğunun belirlenmesine yönelik yeni çalışmalar yapılması önerilmektedir. 


\section{EK-1 SÖZEL VEYA GÖRSEL BASKIN ÖĞRENME STiLINI BELIRLEME ÖLÇEĞi}

\begin{tabular}{|c|c|c|c|c|}
\hline Lütfen size en uygun olan seçeneği işaretleyiniz. & 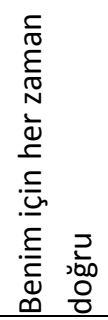 & 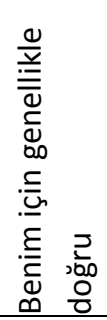 & 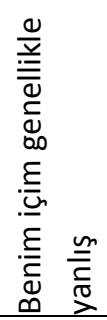 & 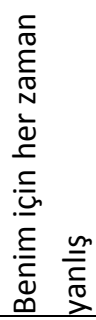 \\
\hline \multicolumn{5}{|l|}{ 1. Sözcükleri kullanmamı gerektiren işleri yapmaktan zevk alırım. } \\
\hline \multicolumn{5}{|l|}{$\begin{array}{l}\text { 2. Yaşantımdaki bazı özel anlarımda gördüklerimi zihnimde } \\
\text { resmederek rahatlamaktan keyif alırım. }\end{array}$} \\
\hline \multicolumn{5}{|l|}{ 3. Çok okuyan birisiyim. } \\
\hline \multicolumn{5}{|l|}{$\begin{array}{l}\text { 4. Yeni bir şey öğrenmeye çalışırken görsel bir anlatımı izlemeyi, } \\
\text { nasıl yapacağımı anlatan yazıyı okumaya tercih ederim. }\end{array}$} \\
\hline \multicolumn{5}{|l|}{$\begin{array}{l}\text { 5. Sözcükleri çoğunlukla yanlış bir şekilde kullandığımı } \\
\text { düşünüyorum. }\end{array}$} \\
\hline \multicolumn{5}{|l|}{ 6. Yeni kelimeler öğrenmekten zevk alırım. } \\
\hline \multicolumn{5}{|l|}{$\begin{array}{l}\text { 7. Odama ya da evime yeni bir şey alacak olsaydım, bunları nereye } \\
\text { koyacağımı kafamda canlandırmaktan hoşlanırdım. }\end{array}$} \\
\hline \multicolumn{5}{|l|}{ 8. Çoğunlukla kendime yazılı notlar hazırlarım. } \\
\hline \multicolumn{5}{|l|}{ 9. Hayal kurmayı severim. } \\
\hline \multicolumn{5}{|l|}{$\begin{array}{l}\text { 10. Genellikle yazılı bir yönerge yerine görsel bir diyagramı } \\
\text { kullanmayı tercih ederim. }\end{array}$} \\
\hline \multicolumn{5}{|l|}{$\begin{array}{l}\text { 11. Birçok şeyi yaparken zihnimde resimler oluşturarak düşünmek } \\
\text { bana yardımcı olur. }\end{array}$} \\
\hline \multicolumn{5}{|l|}{ 12. Kelimelerin eş anlamlılarını düşünmeyi severim. } \\
\hline \multicolumn{5}{|l|}{$\begin{array}{l}\text { 13. Bir şeyi unuttuğumda onu hatırlamak için zihnimde bir resmini } \\
\text { oluşturmaya çalışırım. }\end{array}$} \\
\hline \multicolumn{5}{|l|}{ 14. Yeni kelimeler öğrenmeyi seviyorum. } \\
\hline \multicolumn{5}{|l|}{$\begin{array}{l}\text { 15. Kelime bilgimi (dağarcığımı) arttırmak için çok az zaman } \\
\text { harcarım. }\end{array}$} \\
\hline 16. Düşünürken çoğunlukla aklıma resimler veya görüntüler gelir. & & & & \\
\hline
\end{tabular}




\section{KAYNAKLAR}

Adkins, D. ve Brown-Syed, C. (2002). Accommodating All Learners: Critical Inquiry and Learning Styles In The LIS Classroom. 68th IFLA General Conference And Council. Glasgow.

Arslan, B. ve Babadoğan, C. (2005). İlköğretim 7. ve 8. Sınıf Öğrencilerinin Öğrenme Stillerinin Akademik Başarı Düzeyi, Cinsiyet ve Yaş ile İlişkisi. Eğitim Araştırmaları Dergisi. 21, 3548.

Ateş, A. ve Altun, E. (2008). Bilgisayar öğretmeni adaylarının uzaktan eğitime yönelik tutumlarının çeşitli değişkenler açısından incelenmesi. Gazi Eğitim Fakültesi Dergisi, 28 (3), 125-145.

Best, L.A., Steward, B.M. ve McGuire, K.P. (2008). External Representations and Problem Solving Competence: Do Graphs Improve Problem Solving in Students?. Readings in Education and Technology: Proceedings of ICICTE 2008.

Biggs, J. (2001). Enhancing Learning: A Matter of Style or Approach. Ed.: R.J. Sternberg ve L. Zhang. Perspectives on Thinking, Learning and Cognitive Styles. Lawrance Erlbaum Associates, Mahwah, ss.73 - 102.

Bilasa, P. (2013). Öğrenme Stilleri ve Stil Odaklı Öğretim Tasarımı. S. Büyükalan Filiz içinde, Öğrenme Öğretme Kuram ve Yaklaşımlar (s. 206-233). Ankara: Pegem Akademi.

Bilgin, i. ve Bahar, M. (2008) Sınıf Öğretmenlerinin Öğretme Ve Öğrenme Stilleri Arasındaki İlişkinin İncelenmesi, Gazi Eğitim Fakültesi Dergisi, Cilt 28, Sayı 1 (2008) 19-38.

Boydak, H.A. (2008). Öğrenme Stilleri. Beyaz Yayınları, ISBN:975599047. Türkiye

Büyüköztürk, Ş., Akgün, Ö.E., Özkahveci, Ö. ve Demirel, F. (2004). Güdülenme ve Öğrenme Stratejileri Ölçeğinin Türkçe Formunun Geçerlik ve Güvenirlik Çalışması. Kuram ve Uygulamada Eğitim Bilimleri / Educational Sciences: Theory \& Practice, 4(2) Kasım/November 2004. s. 207-239.

Chen, C. ve Sun, Y. (2012). Assessing the effects of different multimedia materials on emotions and learning performance for visual and verbal style learners. Computers \& Education, 59, s. $1273-1285$.

Childers, T. L., Houston, M. J. ve Heckler, S. E. (1985). Measurement of Individual Differences in Visual Versus Verbal Information Process. Journal of Consumer Research, 12, 125-134.

Çelik, F., ve Şahin, H. (2011). Beden Eğitimi ve Spor Öğretmenliği Öğretmen Adaylarının Cinsiyet ve Öğrenim Gördükleri Sınıf Düzeyleri Bakımından Öğrenme Stillerinin Incelenmesi (MAKÜ Örneği). Buca Eğitim Fakültesi Dergisi, 31, s. 23-38.

Darley, W.K. (1999). The moderating influence of style of information processing on media perceptions and information exposure. Journal of Marketing Communications, 5, s. 181194.

Demir, M.K. (2006). Sınıf öğretmeni adaylarının öğrenme stilleri ve sosyal bilgiler öğretimi. Eurasian Journal of Educational Research, 23, s.28-37.

Demirel, Ö., Erdem, E., ve Başbay, A. (2006). Eğitimde Çoklu Zeka "Kuram ve Uygulama". Ankara: Pegem Akademi. 
Dunn, R. ve Dunn, K. (1993). Teaching secondary science students through their individual learning styles: practical approaches for grades 7-12. Aliyn and Bacon: USA.

Ebenezer, J. V. (2001). A hypermedia environment to explore and negotiate students' conceptions: Animation of the solution process of table salt. Journal of Science Education and Technology, 10 (1), 73-92.

Ekici, G. (2004). Öğrenme Stilleri. A. Ataman içinde, Gelişim ve Öğrenme. Ankara: Gündüz Eğitim ve Yayıncılık.

Ekici, G. (2013). Gregorc ve Kolb Öğrenme Stili Modellerine Göre Öğretmen Adaylarının Öğrenme Stillerinin Cinsiyet ve Genel Akademik Başarı Açısından İncelenmesi. Eğitim ve Bilim, 38(167), s. 211-225.

Ersoy, S., (2003). Illköğretim 6.,7. ve 8. Sını Öğrencilerinin Ingilizce Dersindeki Başarılarına Göre Öğrenme Stilleri Ve Çalışma Alışkanlıklarının Incelenmesi, Yüksek Lisans Tezi, Selçuk Üniversitesi, Konya.

Eskici, M. (2008). Öğrencilerin Öğrenme Stilleri Ille Akademik Başarıları ve Cinsiyet Arasındaki ilişki. Yüksek Lisans Tezi, Trakya Üniversitesi Sosyal Bilimler Enstitüsü.

Felder, R. M. (1993). Reaching The Second Tier: Learning and Teaching Styles In College Science Education. Journal of College Science Teaching, 23(5), s. 286-290.

Felder, R. M. (1996). Matters of Style. American Society For Engineering Education, 6(4), s. 1823.

Felder, R. M. ve Henriques, E. R. (1995). Learning and Teaching Styles In Foreign and Second Language Education. Foreign Language Annuals, 28(1), s. 21-31.

Felder, R. M. ve Silverman, L. K. (1988). Learning and Teaching Styles In Engineering Education. Engineering Education, 78(7), s. 674-681.

Felder, R. M. ve Soloman, B. A. (1998). Learning Styles And Strategies. 10 29, 2013 tarihinde North Caroline State University Web Sitesi:

http://www4.ncsu.edu/unity/lockers/users/f/felder/public/ILSdir/styles.htm adresinden alındı

Gökdağ, M. (2004). Sosyal Bilgiler Öğretiminde Iş̧birlikli Öğrenme, Öğrenme Stilleri, Akademik Başarı ve Cinsiyet ilişskileri. Doktora Tezi, Dokuz Eylül Üniversitesi Eğitim Bilimleri Enstitüsü.

Güven, B. (2008). İlköğretim Öğrencilerinin Öğrenme Stilleri, Tutumları ve Akademik Başarıları Arasındaki İlişkinin İncelenmesi. Türkiye Sosyal Araştırmalar Dergisi, 12(1), s. 25-54.

Güven, Meral (2004). Öğrenme Stilleri ile Öğrenme Stratejileri Arasındaki iliş̧ki. Yayımlanmamış Doktora Tezi. Anadolu Üniversitesi Eğitim Bilimleri Enstitüsü. Eskişehir.

Güven, B., ve Özbek, Ö. (2007). Developing Learning Style Inventory For Effective Instructional Design . The Turkish Online Journal of Educational Technology, 6(2), s. 15-22.

Heckler, S. E., Childers, T. L. ve Houston, M. J. (1993). On the construct validity of the SOP scale. Journal of Mental Imagery,17, 3-4, 119-132

Hsieh, S., Jang, Y., Hwang, G. ve Chen, N. (2011). Effects of teaching and learning styles on students' reflection levels for ubiquitous learning. Computers \& Education, 57, 11941201. 
Karagöz, N., Tezel, Ö., ve Özabacı, N. (2009). Fen ve Teknoloji Dersindeki Öğrenme Biçimlerinin Güdülenme ve Başarıya Etkisi. Eskişehir Osmangazi Üniversitesi Sosyal Bilimler Dergisi, 10(2), s. 277-292.

Keefe, J.W. ve Ferrell, B.G. (1990). Developing a defensible learning style paradigm. Educational Leadership, 48(1), 57-61.

Koçak, T. (2007). Illköğretim 6. 7. 8. Sınıf Öğrencilerinin Öğrenme Stilleri ve Akademik Başarıları Arasındaki Illişkinin incelenmesi. Yüksek Lisans Tezi, Gaziantep Üniversitesi Sosyal Bilimler Enstitüsü.

Kolb, D.A. (1984). Experiential learning: experience as the source of learning and development. Englewood Cliffs, N.J: Prentice-Hall.

Lightner, N.J. ve Eastman, C. (2002). User Preperence For Product Information In Remote Purchase Environments. Journal of Electronic Commerce Research, 3(3), s. 174-186.

Litzinger, T. A., Lee, S. H., Wise, J. C. ve Felder, R. M. (2007). A Psyhometric Study of the Index of Learning Styles. Journal of Engineering Education, 96(4), 309-319.

Liu, T., Kinshuk, Lin, Y. ve Wang, S. (2012). Can verbalisers learn as well as visualisers in simulation-based CAL with predominantly visual representations? Preliminary evidence from a pilot study. British Journal of Educational Technology, 43(6), 965-980.

Mangino, C. ve Griggs, S. A. (2003). Learning sytles in hegher education. In R. Dunn ve S. A. Griggs (Eds.), Synthesis of the Dunn and Dunn Learning-Style Model research: Who, what, when, where, and so what? (pp. 185-188). Jamaica, Ny: St. Johns University, Center fort he Study of Learning and Teaching Styles.

Marks, D.F. (1973). Visual imagery in the recall of pictures. British Journal of Psychology, 64, 17-24.

Meydan, C. H. ve Şeşen, H. (2011).Yapısal Eşitlik Modeli Amos Uygulaması. Detay Yayıncılık.

Okur, M., Bahar, H. H., Akgün, L., ve Bekdemir, M. (2011). Matematik Bölümü Öğrencilerinin Öğrenme Stilleri Ille Sürekli Kaygı ve Akademik Başarı Durumları. Türkiye Sosyal Araştırmalar Dergisi, 15(3), s. 123-134.

Oral, B., ve Avanoğlu, Y. (2011). Öğrenme Stilleri ve Öğrenme Stili Modelleri. B. Oral içinde, Öğrenme Öğretme Kuram ve Yaklaşımlar (s. 267-271). Ankara: Pegem Akademi.

Richardson, A. (1969). Mental Imagery. New York: Springer Publishing Company, Inc.

Richardson, A. (1977). Verbalizer-visualizer: A cognitive style dimension. Journal of Mental Imagery, 1, 109-126.

Pallapu, P. (2007). Effects of Visual and Verval Learning Styles on Learning. Institute for Learning Styles Journal. 1, s.34-39.

Plass, J.L., Chun, D.M., Mayer, R.E., \& Leutner, D. (1998). Supporting visual and verbal learning preferences in a second language multimedia learning environment. Journal of Educational Psychology, 90, 25-36.

Polat, E., Adiguzel,T., \& Akgun, O.E. (2012, April). Adaptive Web-assisted learning system for students with specific learning disabilities: A needs analysis study. Paper presented at International Conference on Global Issues of Early Childhood Education. 
Pritchard, A. (2008). Ways of Learning: Learning Theories and Learning Styles In The Classroom (Second Edition b.). London \& New York: Taylor \& Francis e-Library.

Smutz, R. (2003). The Effect of Teaching Style-Learning Style Match/Mismatch in Learning Effectiveness in Computer-Based Training. Doktora Tezi, Texas A\&M University. Dissertation Abstracts International, 63(8-A), 2845.

Şahinel, M. (2011). Etkin Öğrenme. Ö. Demirel içinde, Eğitimde Yeni Yönelimler (s. 149-165). Ankara: Pegem Akademi.

Schermelleh-Engel, K., Moosbrugger, H. ve Muller, H. (2003). Evaluating the fit of structural equation models: Tests of significance and descriptive goodness-of-fit measures. Methods of Psychological Research-Online, 8, 23-74.

Sönmez, V. (Ed). (2003). Öğretmenlik Mesleğine Giriş. Anı Yayıncılık, Ankara.

Sun, Y. ve Chen, C. (2010). Assessing Learning Emotion for Both the Cognitive Styles of Visualizer and Verbalizer Distributed to Different Types of Multimedia Learning Materials. 2010 International Symposium on Computer, Communication, Control and Automation.

Şimşek, N. (2002), BiG16 Öğrenme Biçemleri Envanteri, Eğitim Bilimleri ve Uygulama Dergisi 1(1), 33-47, ISNN: 13036475

Townsend, C. ve Kahn, B.E. (2014). Influence of Visual versus Verbal Depiction on Assortment Processing, Preceived Variety, and Choice Overload. Journal of Consumer Research, 40(5), s. 993-1015.

Wang, W. (2007). Learning Experiences in Terms of Verbalizer-Visualizer Cognitive Style: Interviewing Verbal and Visual Learners. Yüksek Lisans Tezi, The State University of New York at Buffalo. ProQuest Information and Learning Company.

Wong, N., Rindfleisch, A. ve Burroughs, J.E. (2003). Do Reverse-Worded Items Confound Measures in Cross-Cultural Consumer Research? The Case of the Material Values Scale. Journal of Consumer Research, 30(1), s. 72-91.

Wyer Jr., R.S., Hugn, I.W. ve Jiang, Y. (2008). Visual and verbal processing strategies in comprehension and judgment. Journal of Consumer Psychology, 18, s. 244-257. 


\section{SUMMARY}

Individual differences are very important to consider before choosing instructional methods and techniques properly. One of these differences is style of processing with visual versus verbal. Knowing individuals' style of processing can give us an opportunity to design more individualized teaching and learning processes, and also learning systems. But first we need an instrument to identify dominant style of processing. The purpose of this study was to adapt the Style of Processing Scale (SOP) for Turkish-language which was developed by Childers, Houston and Heckler (1985). The Style of Processing scale comprises of visual and verbal subscales. The original scale has totally 22 items, visual subscale has 11 items; and the verbal scale consists of 11 items. The validity and reliability study of the original scale was conducted with 104 students from Midwestern University. The Cronbach Alfa coefficients of original subscales were found: .81 for visual subscale and .86 for verbal subscale.

The participants of this study are 240 teacher students who were enrolled in Education Faculty of Bartın University. The reliability with internal consistency coefficient Cronbach alpha and confirmatory factor analysis were used in the research. Additionally the items were examined by corrected item-total correlations and t-test for the differences between upper $\% 27$ and lower $\% 27$ groups' mean scores. The Turkish adaptation study of the visual and verbal subscales were conducted in five phases (a) translation, (b) expert review, (c) target audience review, (d) application, and (e) validity and reliability analysis of the scale.

In the first phase, the scale was translated to Turkish by researchers. After the translation, the scale was given to nine experts with a form including original English items and Turkish items to take their opinions. After the making all suggested changes, the items were asked a group of students for checking meaning and clarity. After that the original form of the scale and its Turkish version were administered 17 English language instructors assumed as bilinguals to check language equivalence of the Style of Processing scale. A significant positive and strong relationship was found between the scores $(r=0.94, p<.001)$. Therefore, the translated Turkish version was accepted as equivalent to the original one.

In order to examine the construct validity, CFA was used. The CFA was implemented four times in the analysis. In the best solution, fit indexes of the CFA are $\chi 2 / s d=1.71, R M R=0.063, G F I=0.92$, AGFI $=0.89, \mathrm{RMSEA}=0.055, \mathrm{NNFI}=0.92, \mathrm{CFl}=0.93$. When fit indexes are considered, it can be concluded that all values satisfied the criterion values or very close to them. At the end of the confirmatory factor analysis, totally 6 items was removed from visual and verbal subscales ( 3 items were out of the each from the verbal and visual subscales).

For the reliability of the scale, Cronbach's alpha coefficient is used. Cronbach alpha coefficients were found to be .71 for visual subscale and .69 for visual subscale. The correlations between the total scores of component-items are calculated. The corrected item-total correlations of visual subscale vary 
between 0.57 and 0.27 , the verbal subscale vary between 0.59 and 0.25 . In addition, the differences between items mean scores, and factor means of the upper $27 \%$ and lower $27 \%$ are examined by the $t$ test. For each items, the differences are significant $(p<.01)$.

According to the results of validity and reliability analysis, the Style of Processing Scale Turkish Form is a valid and reliable instrument. Final form of the scale includes totally 16 items, 8 items in each sub factor. It is hoped that the SOP scale will be used in teaching-learning process, scientific research and developing and implementing adaptive-assisted systems. It is planned to improve Turkish SOP scale with studying on different samples and more participants. Also, it is suggested that the SOP scale can be used to investigate visual or verbal individual differences with other variables, such as gender, attitudes, self-efficacy, intelligent quota etc., in new research. 